\title{
In vivo genome editing in animals using AAV-CRISPR system: applications to translational research of human disease
}

\section{[version 1; peer review: 2 approved]}

\author{
Cia-Hin Lau1, Yousin Suh (D2-5 \\ ${ }^{1}$ Department of Mechanical and Biomedical Engineering, City University of Hong Kong, Hong Kong, SAR, China \\ ${ }^{2}$ Department of Genetics, Albert Einstein College of Medicine, Bronx, New York, USA \\ ${ }^{3}$ Department of Ophthalmology and Visual Sciences, Albert Einstein College of Medicine, Bronx, New York, USA \\ ${ }^{4}$ Department of Medicine, Albert Einstein College of Medicine, Bronx, New York, USA \\ 5Institute for Aging Research, Albert Einstein College of Medicine, Bronx, New York, USA
}

V1 First published: 20 Dec 2017, 6(F1000 Faculty Rev):2153
https://doi.org/10.12688/f1000research.11243.1

Latest published: 20 Dec 2017, 6(F1000 Faculty Rev):2153

https://doi.org/10.12688/f1000research.11243.1
Open Peer Review

Approval Status
version 1
20 Dec 2017
Faculty Reviews are review articles written by the
prestigious Members of Faculty Opinions. The
articles are commissioned and peer reviewed
before publication to ensure that the final,
published version is comprehensive and
accessible. The reviewers who approved the final
version are listed with their names and
affiliations.
..................................................................................
1. Jin-Soo Kim, Seoul National University, Seoul,
South Korea
2. Dirk Grimm, Heidelberg University Hospital,
Heidelberg, Germany

Any comments on the article can be found at the end of the article. 
Corresponding authors: Cia-Hin Lau (lauciahin_4275@yahoo.com), Yousin Suh (yousin.suh@einstein.yu.edu)

Competing interests: No competing interests were disclosed.

Grant information: This work was funded by National Institutes of Health grants AG017242, GM104459, and CA180126 (to Yousin Suh).

Copyright: $\odot 2017$ Lau CH and Suh Y. This is an open access article distributed under the terms of the Creative Commons Attribution License, which permits unrestricted use, distribution, and reproduction in any medium, provided the original work is properly cited.

How to cite this article: $\mathrm{Lau} \mathrm{CH}$ and Suh Y. In vivo genome editing in animals using AAV-CRISPR system: applications to translational research of human disease [version 1; peer review: 2 approved] F1000Research 2017, 6(F1000 Faculty Rev):2153 https://doi.org/10.12688/f1000research.11243.1

First published: 20 Dec 2017, 6(F1000 Faculty Rev):2153 https://doi.org/10.12688/f1000research.11243.1 


\section{Introduction}

CRISPR (clustered regulatory interspaced short palindromic repeat)/Cas9-based RNA-guided DNA endonuclease is transforming biomedical science research and has quickly become the preferred genome-editing platform for interrogating endogenous gene function in $v i v o^{1,2}$. The CRISPR-based genome-editing tool has revolutionized the gene-editing technique because of its simplicity in target design, affordability, high efficiency, versatility, and multiplexing capability ${ }^{3}$. The commonly used CRISPR system can be implemented in mammalian cells by co-expressing Cas9 nuclease along with chimeric guide RNA (gRNA), which is derived from a synthetic fusion of the CRISPR RNA array (crRNA) and trans-activating crRNA (tracrRNA) ${ }^{3}$. The target site sequence of gRNA needs to be immediately followed by an optimal protospacer adjacent motif (PAM) sequence according to the species-derived Cas9 nuclease used at the $3^{\prime}$ end $^{4,5}$. The background of and the recent developments in the CRISPRbased targeted genome-editing toolboxes have been extensively reviewed recently ${ }^{1,2,6}$. Various applications of CRISPR technologies for genome engineering and medical research have also been reviewed recently ${ }^{2,6,7}$.

The CRISPR/Cas9 complex can be introduced into the cell in the forms of DNA, messenger RNA (mRNA), or protein ${ }^{8}$. The DNA encoding Cas9 and gRNA can be delivered into the cell using the plasmid and viral expression vectors ${ }^{8}$. Through microinjection, liposome-mediated transfection, electroporation, or nucleofection ${ }^{9}$, several recent studies have shown that the delivery format of active Cas 9 protein/gRNA ribonucleoprotein (RNP) complex has lower off-target effects due to rapid clearance of RNPs from the cell ${ }^{8-10}$ and rapid gene editing as they cleave chromosomal DNA almost immediately after delivery ${ }^{9,10}$ as compared with plasmid DNA transfection. However, the delivery formats of mRNA and protein pose certain technical challenges in vivo. For example, many of the genetic brain disorders affect very large brain areas and more than a single structure in the brain ${ }^{11}$. Therefore, global gene delivery to the central nervous system is a key to achieve effective therapies for neurological disorders. Although a recent study has successfully demonstrated genome editing in the mouse brain by local delivery of RNPs ${ }^{12}$, it is technically challenging to deliver the RNPs globally to the central nervous system. Thus, the viral-based in vivo genome editing remains a popular choice to achieve stable or elevated expression of Cas9 and single-guide RNA (sgRNA) required for establishing animal disease models and therapeutic gene editing in animals. Indeed, it has been demonstrated that systemic delivery of adeno-associated virus (AAV) vectors enabled uniform and broad vector distribution, and subsequently led to extensive and widespread transgene expression in the adult mouse central nervous system ${ }^{13-15}$.

Animal models are preferred over cell models, as they help understand disease mechanisms at the physiological and systemic levels. Somatic mutagenesis via in vivo genome editing provides an ideal platform to accelerate the generation of transgenic animals for rapid exploration of human diseases and correcting genetic defects in gene therapy. In vivo genome editing also avoids laborious germline targeting and high costs of maintaining transgenic neonates through adulthood in animals with a long life span. Obviously, somatic mutagenesis in adult animals has proven technically more challenging than gene editing of one-cell-stage embryos or zygotes or pluripotent stem cells. The major hurdle is to efficiently deliver the CRISPR components in vivo. To date, various viral, non-viral (for example, lipid nanoparticles), and physical (for example, hydrodynamic injection) based delivery approaches of the CRISPR/Cas9 complex have been adopted for in vivo genome editing. The pros and cons of these delivery methods have been extensively reviewed recently ${ }^{16-18}$.

Given the great potential of viral vectors in gene and cell therapy, five major classes of viral vectors-retroviruses ${ }^{19}$, lentiviruses ${ }^{20,21}$, adenoviruses $^{22,23}, \mathrm{AAVs}^{24,25}$, and baculoviruses ${ }^{26,27}$-have been employed to deliver CRISPR components into mammalian cells for targeted genome editing. The advantages and disadvantages of using these viral vectors for in vivo delivery of the CRISPR transgenes have been extensively reviewed ${ }^{24,28-30}$. In Table 1 , we listed general characteristics and applications of various viral delivery vectors. Among these, the AAV vector is the overall focus of this review. The AAV system provides major advantages for research and therapeutics, including a very mild immune response and toxicity elicited by AAV in animal models. Moreover, AAVs remain primarily episomal upon transduction, avoiding random integration of the viral genetic materials into the host genome that can disrupt neighboring gene function and cause insertional mutagenesis ${ }^{31}$. Indeed, there has been no reported case of disease caused by AAV in humans ${ }^{31}$. Additionally, AAV can exist longterm as concatemers in non-dividing cells for stable transgene expressions $^{31}$. Given a good safety profile of AAV and therapeutic efficacy in a wide range of animal models and human clinical trials (ClinicalTrials.gov), AAV is thought to be one of the most suitable viral vectors for gene therapeutic applications and gene transfer in vivo. Furthermore, there is a wide range of AAV serotypes that can be selected to infect specific tissues in vivo. For these reasons, here, we provide an overview of the state of the art of various AAV-CRISPR systems as well as their principal vector designs for in vivo genome editing in animals. Senís and colleagues were amongst the first to exploit and demonstrate the use of the AAV vectors to package, deliver, and express CRISPR components for targeted gene editing in hard-to-transfect cells and the liver of adult mice ${ }^{32}$. Subsequently, an increasing number of the studies used AAV vectors to deliver the CRISPR components into animals for in vivo genome editing. Of note, for certain applications such as packaging of a very large transgene ${ }^{29,33}$, genome-wide screening ${ }^{20,34,35}$, and production of vaccines and recombinant proteins ${ }^{36,37}$, the other viral vectors may be a better option. However, in-depth discussions of the other viral delivery vehicles for the CRISPR components are beyond the scope of this review.

Here, we aim to review various AAV-CRISPR systems recently demonstrated in mice and to discuss how the combined use of tissue-specific minimal promoters, AAV serotypes, different routes of administration, and small Cas 9 orthologues has enabled investigators to achieve maximal efficiency and specificity for in vivo genome editing. In addition, we discuss the clinical implications and potential strategies to overcome off-target effects, 

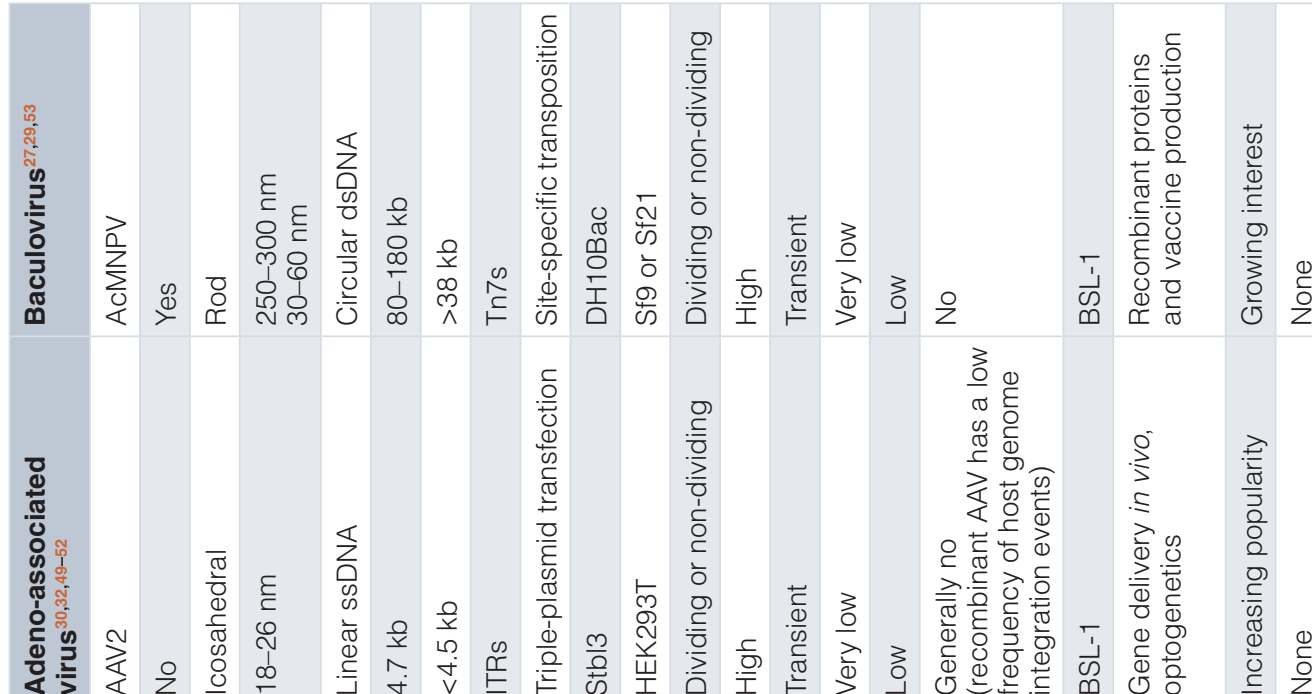

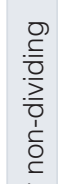
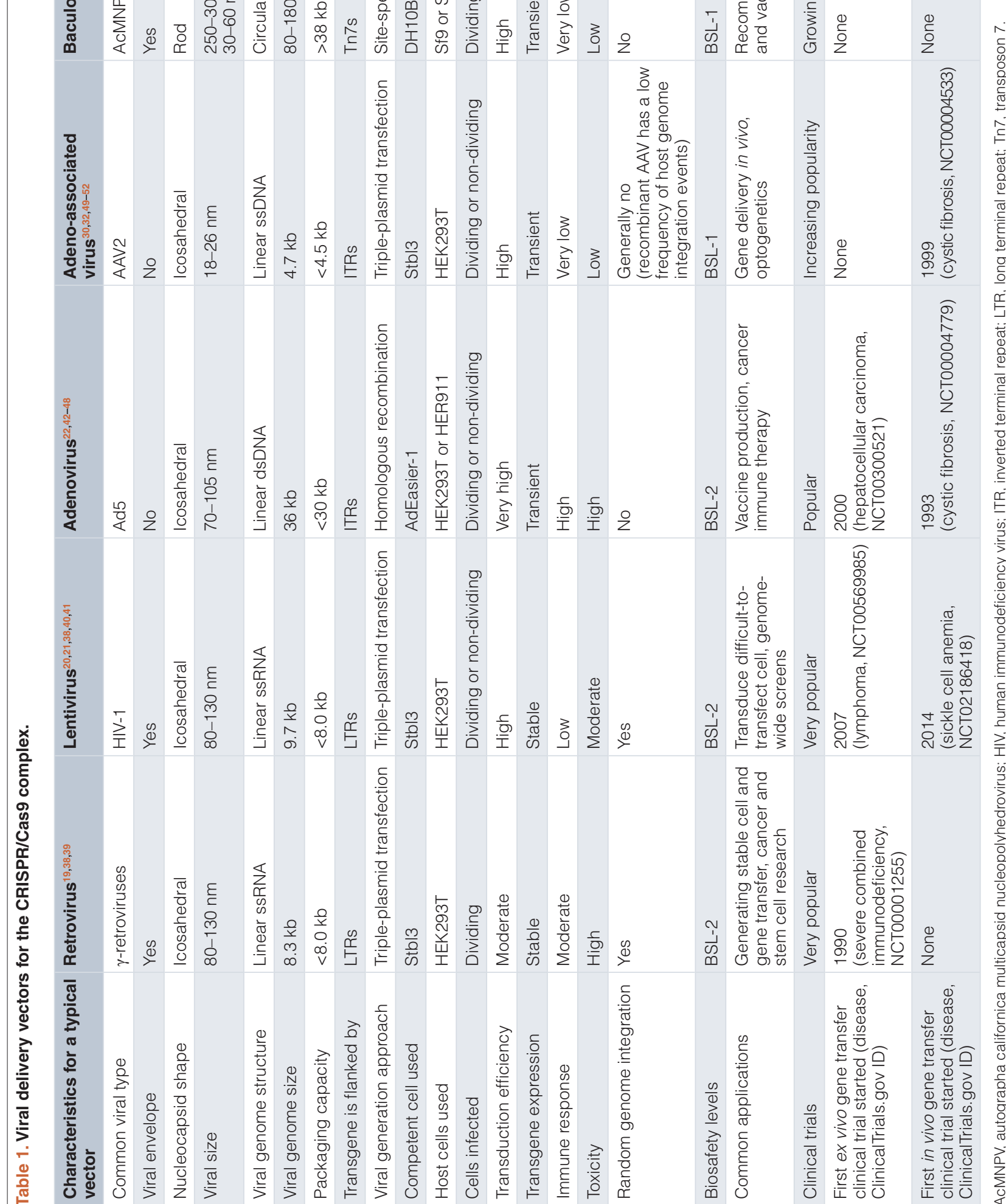
immunogenicity, and toxicity associated with CRISPR components and AAV delivery vehicles. Finally, we discuss the promises and hurdles associated with ongoing ex vivo gene therapy clinical trials.

\section{AAV-CRISPR-based in vivo genome editing in mice}

At least 33 published studies successfully used CRISPR/Cas9 alongside AAV vectors for in vivo genome editing in mice (Table 2). The AAV-CRISPR system is particularly useful for editing disease-associated genes in the brain or central nervous system of mice because of the inability of most cationic nanocarriers to cross the blood-brain barrier, high transduction efficiency of AAV vectors in the brain, and non-dividing properties of neurons for long-term therapeutic effects. The AAV-CRISPR system has also been successfully used to restore the gene function in muscle-associated diseases such as Duchenne muscular dystrophy ${ }^{54-57}$ and diseases associated with the eye ${ }^{5,58-60}$, liver ${ }^{4,49,61}$, heart ${ }^{62-64}$, and lung ${ }^{65}$. This AAV-CRISPR-mediated gene editing in mice provided proof-of-principle studies for human disease modeling, gene therapy, or gene functional characterizations. We discuss recent developments and advancements in four critical aspects of the AAV-CRISPR system that have enabled efficient and precise in vivo genome editing in mice.

\section{Small Cas9 orthologues}

Even though the AAV vector is an extremely attractive delivery vehicle for CRISPR, its relatively small viral genome-packaging capacity has limited its use for delivering large transgenes. Using dual-vector AAV system or smaller Cas9 orthologues along with truncated regulatory elements (promoter and polyadenylation signal) has greatly circumvented the transgene packaging issue (Figure 1A). Owing to a small AAV viral genome-packaging capacity $(\sim 4.8 \mathrm{~kb})$, it has been technically challenging to co-package Streptococcus pyogenes-derived Cas9 (SpCas9) (4.1 kb) and multiple sgRNAs into all-in-one AAV vectors for multiplex genome editing. Recently, it has been demonstrated that when very small promoters were used (for example, miCMV promoter and $\mathrm{H} 1$ promoter to drive the expressions of SpCas9 and its gRNA, respectively), it was possible to package both SpCas9 and its gRNA into a single vector ${ }^{32}$. However, the number of promoters that can be selected for tissue-specific transduction is limited. To circumvent this issue, the previously reported dual-vector system was adopted to express SpCas9 nuclease from one vector and to express its gRNAs together with a fluorescent reporter gene from another vector ${ }^{25}$. Recently, St1Cas9 $(\sim 3.3 \mathrm{~kb})$ from Streptococcus thermophilus ${ }^{66}$ and a rationally designed truncated form of $\mathrm{SpCas} 9^{67}$ were developed to fit SpCas9 and its gRNA into a single AAV construct. Unfortunately, St1Cas9 requires a more complex PAM sequence that limits the number of targetable loci ${ }^{66}$, and truncated SpCas9 has a much lower efficiency than its wild-type counterpart ${ }^{67}$.

To overcome these drawbacks, other recently discovered small Cas9 orthologues, including Staphylococcus aureus-derived Cas9 (SaCas9, $3.16 \mathrm{~kb})^{4}$ and Campylobacter jejuni-derived Cas9 (CjCas9, $2.95 \mathrm{~kb})^{5}$, have been used to package the Cas9 and its gRNA into a single AAV delivery vehicle for in vivo genome editing. To date, at least 11 independent in vivo studies have used the AAV-SaCas9 system to edit disease-associated genes in a variety of tissues, including brain ${ }^{68}$, muscle ${ }^{54,55,57,69}$, retina ${ }^{58}$, heart ${ }^{70}$, and liver ${ }^{4,49,71}$. More recently, the quadruplex gRNAs/SaCas9 vector consisting of SaCas9 and multiplex sgRNAs was successfully delivered using AAV-DJ/8 for in vivo excision of HIV-1 proviral DNA in various solid tissues/organs via a single intravenous injection in humanized bone marrow/liver/thymus (BLT) mice with chronic HIV-1 infection ${ }^{72}$. In the all-in-one vector system, CjCas9 can be packaged with multiple gRNAs and even a fluorescent reporter gene into a single AAV vector ${ }^{5}$. Even though CjCas9 represents the smallest Cas9 orthologue characterized to date, only one in vivo study has demonstrated the use of AAV vectors to deliver CjCas9 into the mouse's retina for the treatment of age-related macular degeneration because of the recent development of $\mathrm{CjCas}^{5}$. Excitingly, AAV-CjCas9 offers the possibility of editing multiplex genes and tracking the expression of fluorescent reporter genes at high efficiency by simply introducing a single type of AAV vector into the mouse body. The CRISPR-mediated genome-editing specificities can be further improved by adopting truncated gRNAs ${ }^{73}$ and small chemical molecules to regulate Cas9 activity $^{74}$ or to enhance doublestranded break-induced homologous recombination efficiency ${ }^{75}$ without sacrificing on-target genome-editing efficiencies.

\section{Natural and engineered AAV serotypes}

Multiple naturally occurring AAV serotypes have been harnessed to deliver the CRISPR/Cas9 complex into different tissues and organs in mice (Figure 1B). AAV1 is particularly efficient to drive CRISPR transgene expression in the brain ${ }^{25,65,76}$, whereas AAV8 appears well suited for the transduction of liver ${ }^{4,49,61,71,77}$ and muscle ${ }^{55}$ in mice. AAV9 has the general ability to transduce all major tissues, including muscle ${ }^{54,56,69}$, retina $^{5}$, heart ${ }^{62-64,78}$, and lung ${ }^{65}$, in mice. Recently, the AAV9-CRISPR system has been successfully used to identify functional tumor suppressors in glioblastoma by performing high-throughput mutagenesis in the brain of conditional-Cas9 mice to recapitulate human glioblastoma ${ }^{79} \cdot \mathrm{AAV}^{59}$ and $\mathrm{AAV} 5^{58}$ have also been used to transduce retina, whereas AAV6 $6^{57}$ enables CRISPR-mediated gene editing in muscle tissue.

In order to alter tropism, reduce blockage by neutralizing antibodies, or enhance transduction efficiency, AAV capsids have been chemically or genetically modified to produce hybrid capsids by combining the properties of multiple serotypes, capsid shuffling, directed evolution, rational mutagenesis, or carrying peptide insertions that introduce the novel receptor-binding activity. AAV variants with engineered capsids (AAV2-retro, AAV2g9, AAV-DJ, and AAV-DJ/8) have been used to package CRISPR for transduction in the mouse brain. An in vivo-directed evolutionengineered AAV variant, rAAV2-retro, permits robust retrograde access to projection neurons in functionally connected and highly distributed networks with a high efficiency for neural circuit dissection and in vivo genome editing ${ }^{68}$. An AAV chimera derived from AAV2 and AAV9, AAV2g9, enables preferential, robust, and widespread neuronal transduction within the mouse brain for CRISPR/Cas9-mediated gene deletion for the treatment of neurological disorders ${ }^{80}$. To provide substantially higher infectivity rates across a broad range of tissues than any known native serotypes, 


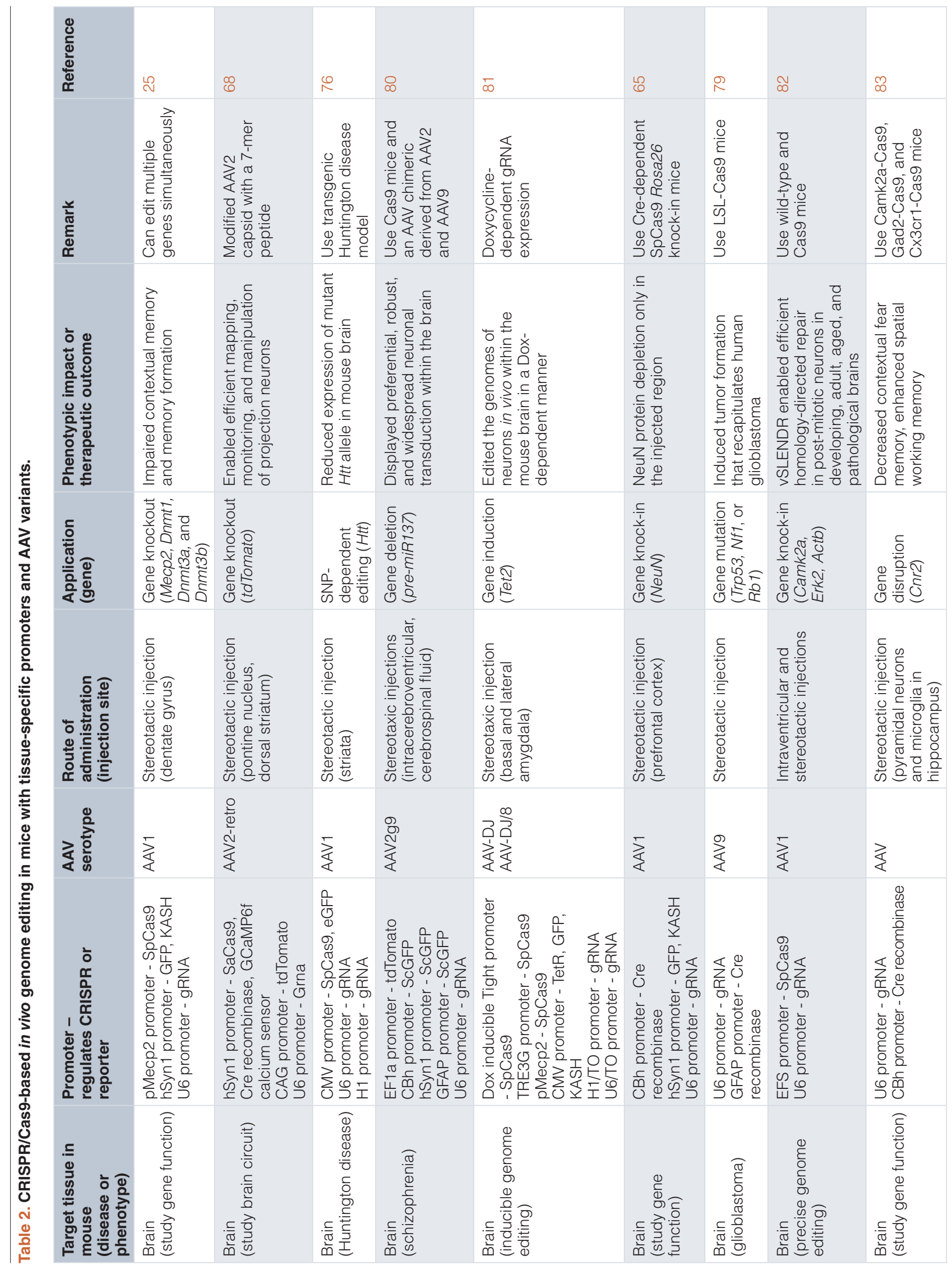




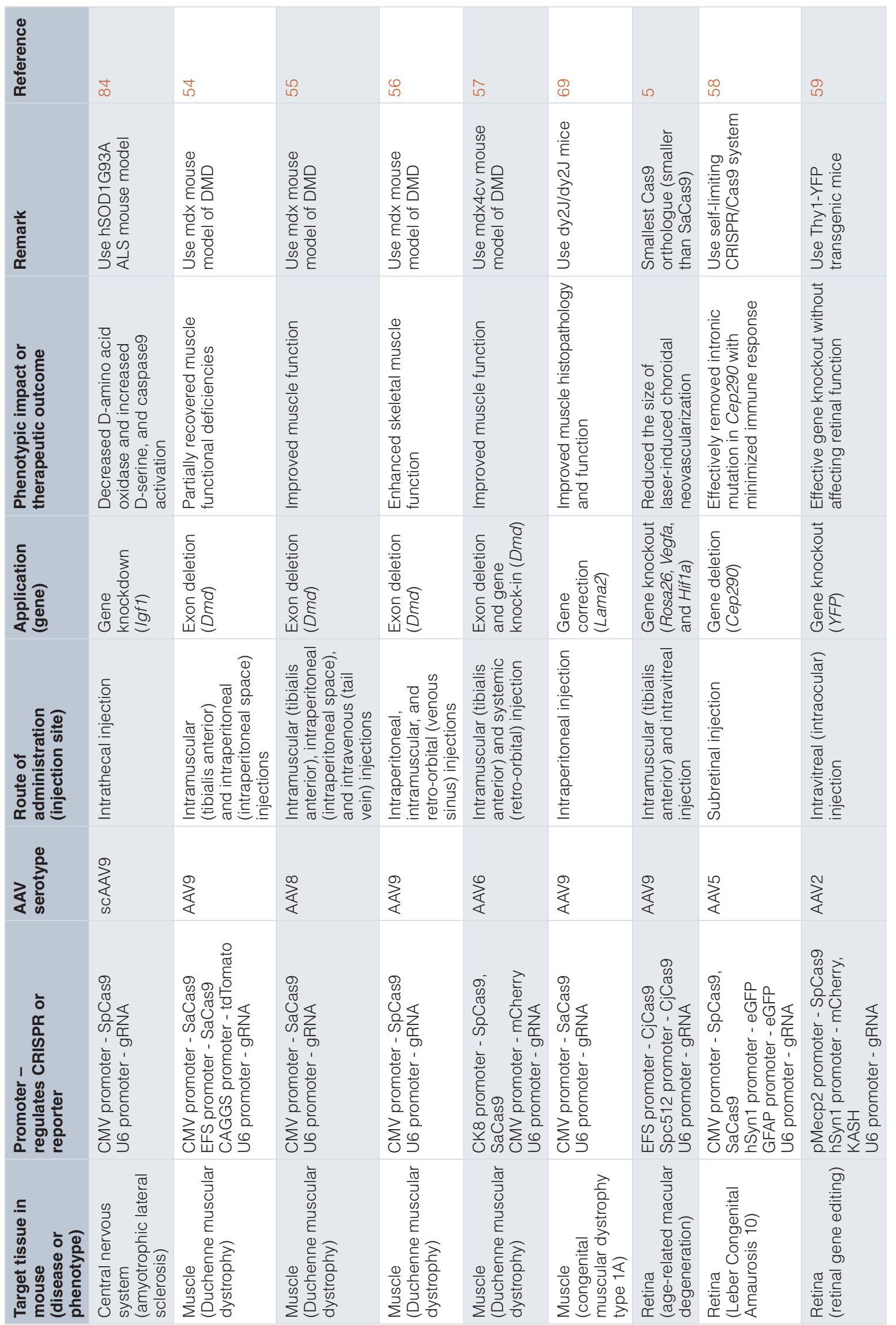




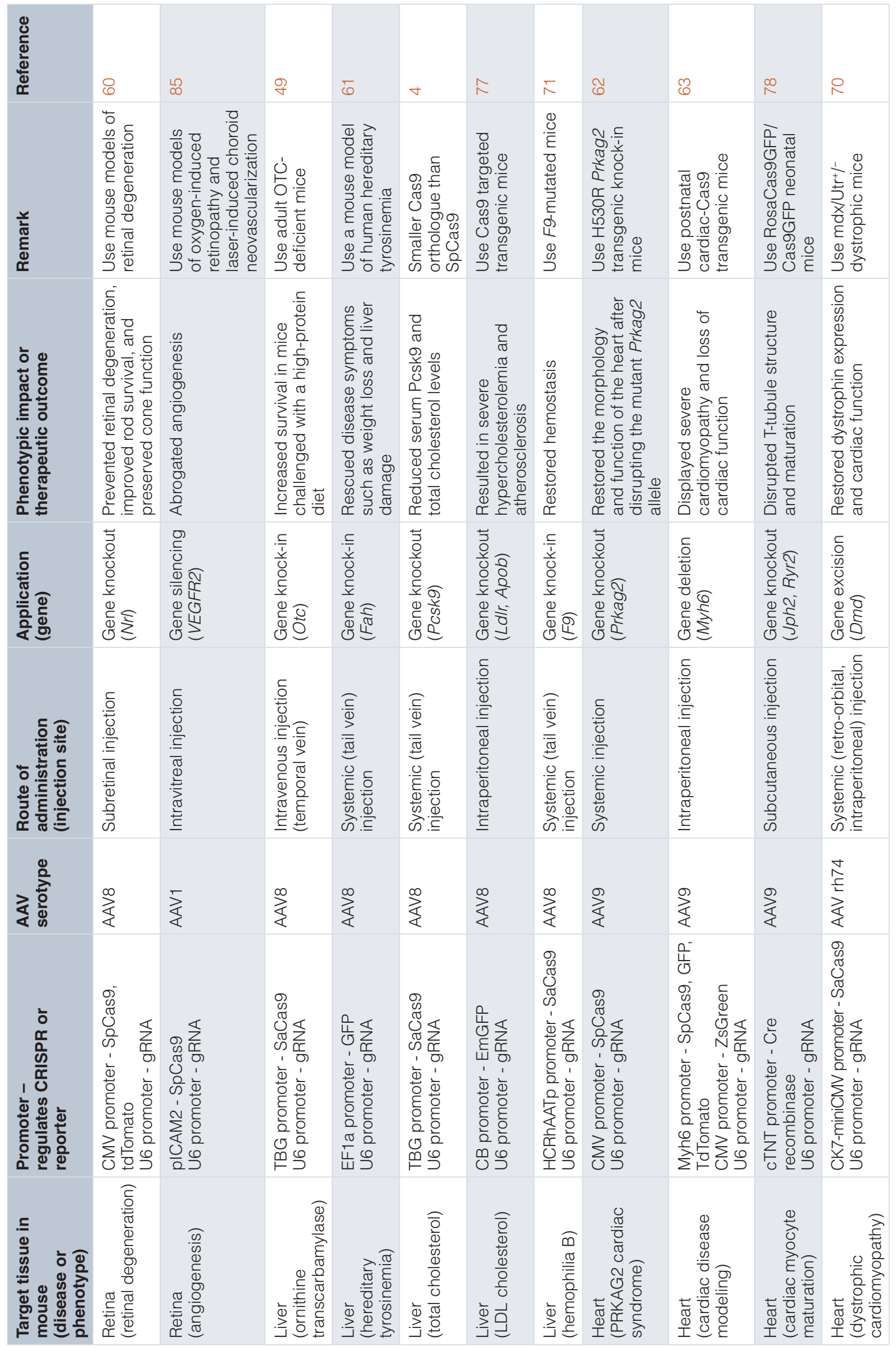




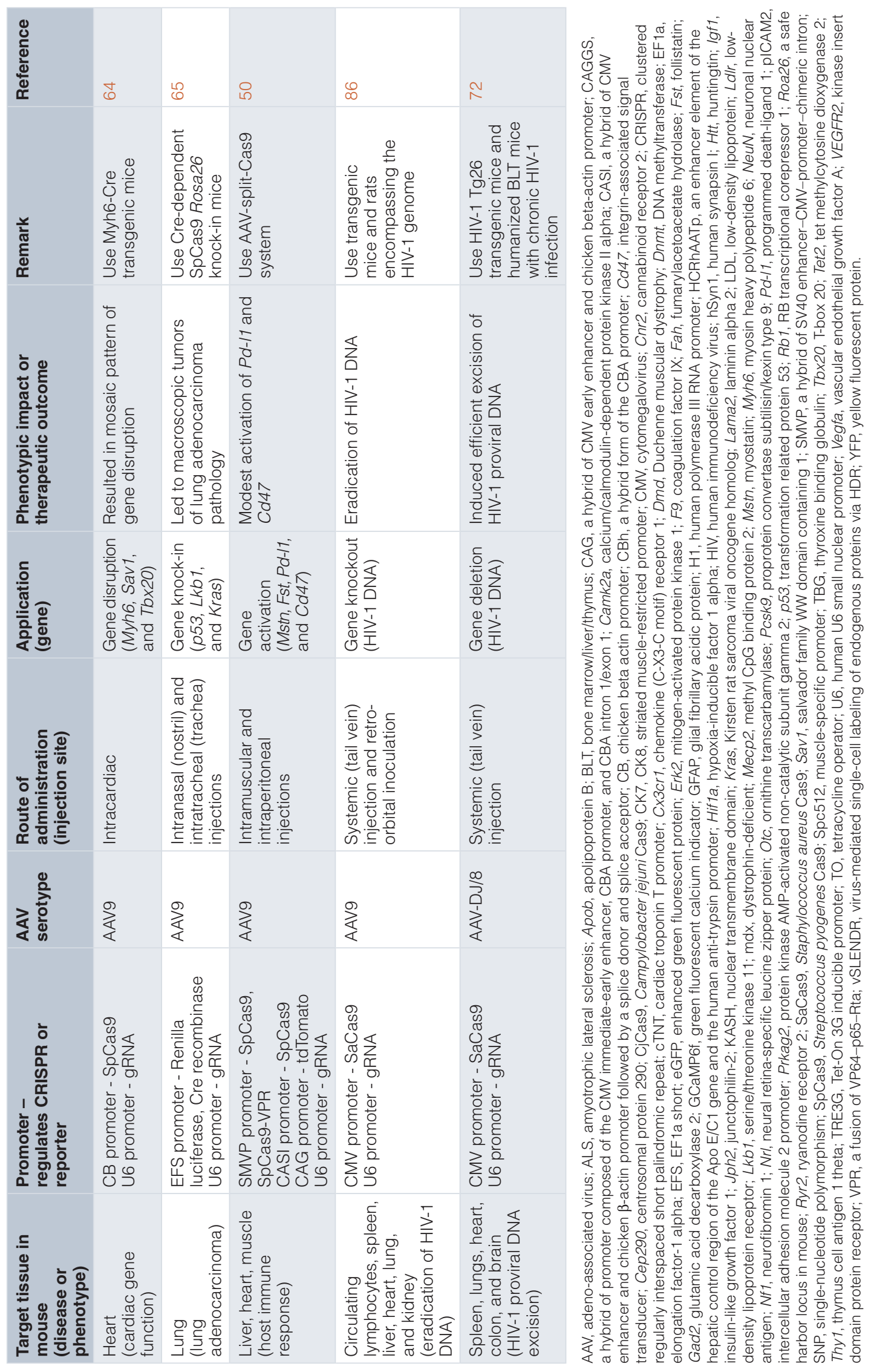


A

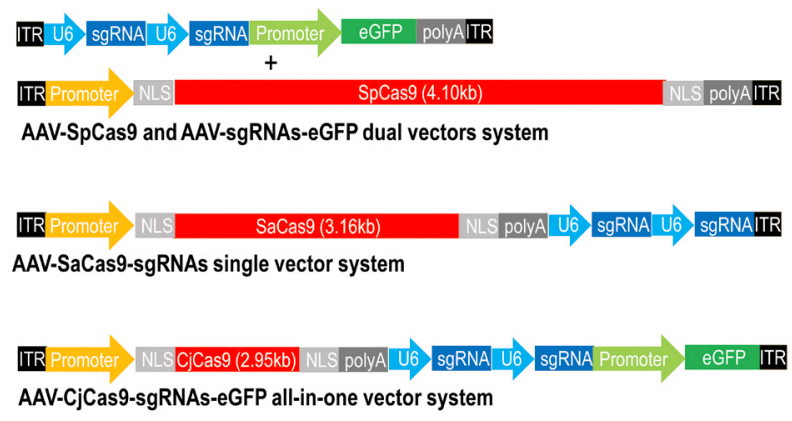

C

Minimal tissue-specific promoters for driving CRISPR expression
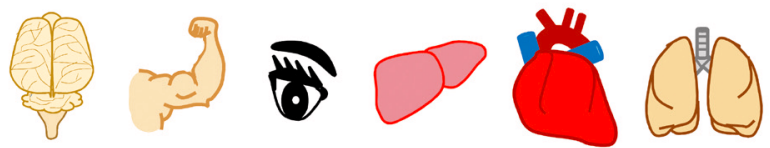

$\underline{\text { brain }} \underline{\text { muscle }}$

p) $\overline{\mathrm{Mecp}} 2$

hSyn1

TRE3G

Tight

EFS

CK8

$\frac{\text { retina }}{\text { EFS }}$

Spc512

CMV

pMecp2

pICAM2

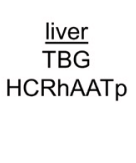

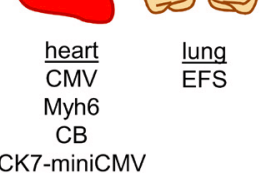

B

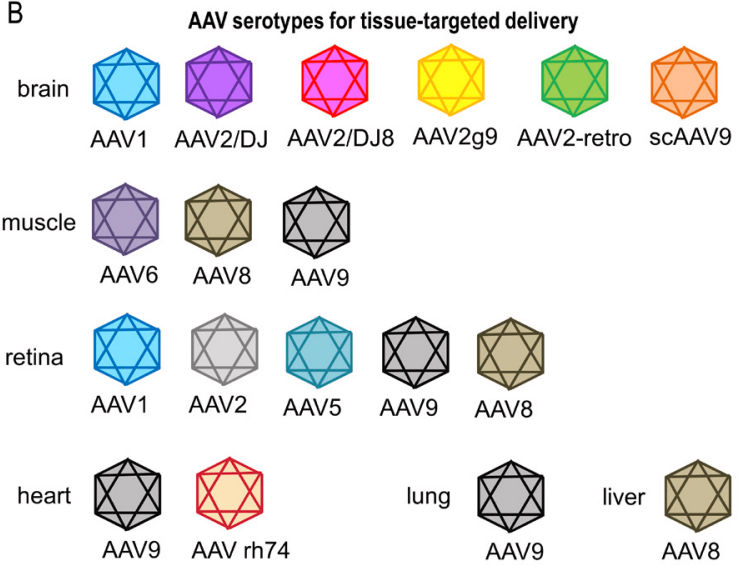

Figure 1. CRISPR/Cas9-based in vivo genome editing by using small Cas9 orthologues, different routes of AAV administration, tissuespecific minimal promoters, and AAV serotypes. (A) AAV-CRISPR vectors. Campylobacter jejuni-derived Cas9 (CjCas9) is the smallest Cas9 orthologue (984 amino acids, $2.95 \mathrm{~kb}$ ). Staphylococcus aureus-derived Cas9 (SaCas9) (1,053 amino acids, $3.16 \mathrm{~kb})$ is smaller than the most widely used Cas9 derived from Streptococcus pyogenes (SpCas9) (1,368 amino acids, $4.10 \mathrm{~kb}$ ). Owing to the large size of SpCas9, the SpCas9 gene and two gRNAs are packaged into two separate AAV vectors. The SpCas9-based dual-vector system enables one vector to express SpCas9 and another to express multiple gRNAs and a fluorescent reporter gene. Two gRNAs can be packaged with the SaCas9 into a single AAV vector if minimal promoter and polyadenylation signal are used. In the all-in-one vector system, CjCas9 enables packaging with two gRNAs and a fluorescent reporter gene, enhanced green fluorescent protein (eGFP), into a single AAV vector. (B) AAV serotypes for tissue-targeted delivery. (C) Tissue-specific minimal promoters for driving CRISPR expression. (D) Different routes of AAV administration into various tissues of a mouse. AAV, adeno-associated virus; CRISPR, clustered regulatory interspaced short palindromic repeat; gRNA, guide RNA.

the AAV-DJ was engineered by DNA family shuffling to create a hybrid capsid from eight different native serotypes ${ }^{87}$. AAV-DJ/8 was created by introducing two point mutations in the heparinbinding domain of AAV-DJ to increase uptake in brain tissue in vivo, leading to a similar ability to infect heart and brain tissues with AAV8 and AAV9 ${ }^{87,88}$. In fact, AAV-DJ/8 has been successfully used alongside the CRISPR/Cas9 system with doxycyclinedependent gRNA expression for inducible genome editing of neurons in vivo within the mouse brain ${ }^{81}$. AAV-DJ/8 has also been successfully used to package and deliver the CRISPR/SaCas9 vectors for in vivo excision of HIV-1 proviral DNA in animal models $^{72}$.

Recently, the capsids of AAV9, which is the most efficient native serotype characterized to date for in vivo transduction of the brain, have been further engineered for better performance in transductions and tissue targeting specificity. These include AAV-PHP.B (a chimeric AAV9 variant generated by inserting a 7-mer sequence, TLAVPFK, on AAV9 capsid) ${ }^{13}$, AAV-AS (a chimeric AAV9 variant generated by inserting a poly-alanine peptide on AAV9 capsid) $^{14}$, and AAV9/3 (double tyrosine-mutant form of AAV9) ${ }^{89}$, all of which were shown to be more efficient in transductions of the adult mouse central nervous system after intravenous injection compared with the wild-type AAV9. Furthermore, some of these engineered AAV capsids could de-target the native AAV tropism without affecting vector production, capsid assembly, infectivity, and gene transfer. Therefore, these novel engineered vectors offer promising options to package the CRISPR/Cas9 complex to efficiently edit disease-associated genes in the mouse brain or any other tissues. Additionally, self-complementary AAV9 (scAAV9) can be used to significantly decrease the time required for the onset of CRISPR expression in the central nervous system of mice ${ }^{84}$. Second-strand synthesis is a rate-limiting step for efficient transduction by recombinant AAV vectors ${ }^{31}$. The 
use of double-stranded self-complementary AAV (scAAV) has improved the transduction efficiencies by bypassing the secondstrand synthesis step, but cloning capacity was further reduced to accommodate the complementary strand ${ }^{90}$.

\section{Tissue-specific minimal promoters}

A tissue-specific promoter is important to ensure the expression of the CRISPR transgene in a tissue- or organ-specific manner. Various truncated or minimal tissue-specific promoters have been used to drive the expression of CRISPR in specific tissues upon injection of the AAV vectors into the mouse body (Figure 1C). For example, the 235 base pair (bp) mouse pMecp2 (methyl CpG binding protein 2) and 485 bp human hSyn1 (human synapsin I) promoters have been used to efficiently and specifically drive the expression of CRISPR and other transgenes in the mouse brain $^{25}$ and retina ${ }^{59}$. A striated muscle-restricted promoter, CK8, enabled specific expression of SpCas9 and SaCas9 for gene editing in the muscle of the mdx mouse model of Duchenne muscular dystrophy upon intramuscular (tibialis anterior) or systemic (retro-orbital) injection of AAV6 vectors ${ }^{57}$. The liver-specific TBG (thyroxine binding globulin) (49 $^{49}$ and cardiac-specific Myh6 (myosin heavy polypeptide 6) ${ }^{63}$ promoters have been successfully used to drive the expression of CRISPR for in vivo genome editing in mouse liver and heart, respectively. More general promoters such as CMV (cytomegalovirus) $^{54,58,60,62}$ and EFS (elongation factor-1 alpha short $)^{5,65}$ can be used to express the CRISPR in multiple tissues, including muscle, retina, heart, and lung, for simultaneous gene editing of various tissues in mice. Compared with the CMV promoter, the elongation factor-1 alpha (EF1a) promoter tends to give more consistent and prolonged expression regardless of cell type or physiology ${ }^{91,92}$. EF1a is more stable in long-term culture because it maintains high transgene expression and stability and the copy number of episomal vectors ${ }^{91}$. Thus, despite a stronger gene expression driven by the CMV promoter in many mammalian cell types, EF1a is preferred for efficient transgene expression in mouse embryonic stem cell lines ${ }^{93}$ and for engineering stable tumor cell lines ${ }^{92}$. The library of minimal tissue-specific promoters alongside AAV vectors used for controlling the expression of CRISPR or other transgenes in vivo is expanding with the development of more tightly regulated synthetic hybrid promoters, such as widely used CAG, CAGGS, CASI, CBh, GFAP, TRE3G, SMVP, Spc512, H1/T0, CK7-miniCMV, pICAM2, HCRhAATp, and Tight promoters (Table 2).

Chimeric gRNA expression is frequently driven by an RNA polymerase III promoter, most often by the human U6 small nuclear (U6) promoter. The human U6 promoter has been shown to be more efficient than its murine homolog for short hairpin RNA (shRNA) expression in both human and murine cells ${ }^{94}$. The human U6 promoter was also proven more efficient than the human $\mathrm{H} 1$ promoter in driving shRNA expression for the longterm inhibition of gene expression in vitro and in vivo ${ }^{95}$. However, the use of the U6 promoter to overexpress shRNAs in vivo can induce severe hepatotoxicity and inflammatory side effects due to abundant shRNA production ${ }^{96}$. The weaker $\mathrm{H} 1$ promoter may offer a safer option in this case, but its therapeutic efficacy is dependent on the sequence of the shRNA ${ }^{96}$. Some promoters require a particular nucleotide as the transcription start site (TSS) to initiate transcription. For instance, the human or mouse U6 promoters require a guanine nucleotide $(\mathrm{G})$ at the $5^{\prime}$ end of the transcript for effective transcription ${ }^{97}$. To use the U6 promoter for driving gRNA expression, the first nucleotide of the transcribed gRNA should be a $\mathrm{G}$ to maximize U6 promoter activity ${ }^{97}$. If the $\mathrm{G}$ is absent at the TSS of the gRNA sequence, the human RNA polymerase III promoter $\mathrm{H} 1$ can be used to drive the expression of the gRNA $^{76}$. The use of $\mathrm{H} 1$ promoter-expressed gRNAs could enhance the versatility of the CRISPR technology by expanding the targetable genome ${ }^{98}$. For multiplex CRISPR/Cas9-based genome editing such as large genomic DNA deletion or synergistically enhanced gene activation and repression, four independent polymerase III promoters (human U6 promoter, murine U6 promoter, 7SK, and $\mathrm{H1}$ ) can be used to express four gRNAs in a single expression cassette ${ }^{21}$. The use of distinct polymerase III promoters can avoid the problem of genetic recombination in a viral vector and the loss of the proximal gRNA due to identical DNA sequences of the promoters ${ }^{99}$. The doxycycline-dependent promoters such as H1/TO and U6/TO can also be used for inducible in vivo genome editing by supplying animals with Dox-containing food to regulate the expression of the gRNA in a Dox-dependent manner ${ }^{81}$. The introduction of Dox inhibits Tet repressor (TetR) binding and induces gRNA expression ${ }^{81}$.

\section{Local and global delivery of AAV vectors}

The route of administration of AAV-CRISPR vectors into the mouse body also determines the efficacy and specificity of gene editing for in vivo therapeutics (Figure 1D). Given the inability of the most native AAV serotypes (except for AAV9 ${ }^{100}$, $\mathrm{AAVrh} 8^{101}$, and AAVrh10 ${ }^{102}$ ) to cross the blood-brain barrier, stereotactic $^{25,65,76}$ and intrathecal ${ }^{84}$ injections are still the preferred routes to systemic injection in order to introduce the AAV-CRISPR vectors into specific regions of the mouse brain or central nervous system for therapeutic gene editing. For the stereotactic injection, AAV-CRISPR vectors are intracranially injected into the brain by using a stereotaxic apparatus and the injection micropipette. In the intrathecal injection approach, AAV-CRISPR vectors are injected into the spinal canal or subarachnoid space to reach cerebrospinal fluid. For efficient therapeutic gene editing in the mouse muscle tissue, intramuscular (via tibialis anterior), intraperitoneal (via intraperitoneal space), or intravenous (via the tail vein, temporal vein, and retro-orbital) injections are the preferred methods to introduce AAV-CRISPR vectors, as have been demonstrated for the $\mathrm{mdx}$ mouse model of Duchenne muscular dystrophy ${ }^{55-57}$. Subretinal ${ }^{58,60}$ or intravitreal ${ }^{59,85}$ injections are used to deliver AAV-CRISPR vectors into the mouse retina for gene editing. As most of the AAV vectors will accumulate in the mouse liver tissue upon systemic injection, intravenous injection by tail vein or temporal vein can efficiently edit the genes associated with liver diseases ${ }^{4,49,71}$. Systemic injection remains preferred to local injection in the liver tissue because the delivery is more uniform and the distribution of viral vectors is broader. It is also a good delivery mode for gene editing in multiple tissues, as it is almost non-invasive to the body. On the other hand, intracardiac ${ }^{64}$, subcutaneous ${ }^{78}$, intraperitoneal $^{63}$, or systemic $\mathrm{c}^{62,70}$ injection has been used to introduce AAV9 vectors carrying CRISPR transgene into the 
mouse heart for gene editing. Intranasal and intratracheal injections are used to locally deliver the AAV-CRISPR vehicles into the mouse lung tissue ${ }^{65}$. Therefore, the selection of an effective route of injections is dependent on the target tissue, AAV serotypes, and tissue-specific promoters used.

\section{CRISPR/Cas9-based human gene and cell therapies}

In August 2016, the first human clinical trial using a CRISPR-based gene-editing technique was started for cancer immunotherapy of metastatic non-small cell lung cancer ${ }^{103}$. Subsequently, 10 more early phase clinical trials are underway (ClinicalTrials.gov). One of these clinical trials has proceeded to phase 2 for the treatment of advanced esophageal cancer. Six of these early phase clinical trials are using the CRISPR/Cas9 system to create genetically altered immune cells, which are infused back into patients with an advanced stage of lung, bladder, prostate, renal, gastric, esophageal, or nasopharyngeal carcinoma or lymphoma to target and eradicate cancer cells (Table 3). In general, the programmed cell death protein 1 gene (PDCD1) will be knocked out in autologous $\mathrm{T}$ cells. These engineered $\mathrm{T}$ cells then will be selected and expanded ex vivo before infusion back into the patients. PDCD1, more commonly known as PD-1, is an inhibitory cell surface receptor involved in the regulation of T-cell function during immune response and tolerance. Knockout of $P D-1$ in T cells extracted from the patient's blood could prevent cells' immune response from switch-off after re-introduction of the gene-edited cells into the patient's bloodstream and attack and defeat the cancer cells ${ }^{104}$. In fact, antibodies (for example, nivolumab and pembrolizumab) that neutralize PD-1 with high response and low adverse effect rates have been successfully used for cancer immunotherapy in human clinical trials ${ }^{105,106}$. Gene editing is expected to inhibit PD-1 with a greater certainty, and by multiplying the cells in the laboratory, scientists can enhance the efficacy of triggering an immune response against tumors ${ }^{104}$.

These interventional studies aimed to evaluate the clinical response, safety, and maximal tolerant dose of the CRISPRmediated $P D-1$ knockout $\mathrm{T}$ cells in treating advanced-stage malignancies upon being infused back into patients. An anticancer chemotherapy drug, cyclophosphamide, will be administered for a few days to modify the immune micro-environment before cell infusion or to deplete regulatory $\mathrm{T}$ cells (Tregs) before collecting peripheral blood. After cell infusion, the interleukin-2 cytokine that has both immune-modulating and anti-tumor properties will be administered to sustain the survival of infused $\mathrm{T}$ cells. For cancer immunotherapy of lymphoma or leukemia, an anti-metabolite anti-cancer chemotherapy drug, fludarabine, will be co-administered with the cyclophosphamide before cell infusion. Biomarkers and immunological markers will be closely monitored after cell infusion to determine whether the injections are causing any serious adverse effects and to evaluate whether the patients will receive benefits from the treatment.

In another CRISPR/Cas9-based ex vivo gene therapy clinical trial, the CRISPR/Cas9 complex will be used to disrupt the $\mathrm{C}-\mathrm{C}$ chemokine receptor type 5 (CCR5) gene in the $\mathrm{CD} 34^{+}$hematopoietic stem or progenitor cells from donors (NCT03164135). Then, these CCR5 modified CD34+ cells from donors will be infused into the HIV-infected patients with AIDS and hematological malignancies. In principle, HIV-1 virus requires CCR5 receptor on the surface of host immune cells (for example, $\mathrm{T}$ cells) to infect the cell; hence, disrupting or blocking the CCR5 receptor may make the immune cell resistant to the virus infection. When the CCR5-modified immune cells from the donor are mixed inside the body with the CCR5-positive immune cells from HIV-infected patients, the HIV-1 virus will infect and kill the CCR5-positive immune cells and the CCR5-negative immune cells will survive and eventually take over the immune function. The primary objectives of this clinical trial are to determine the safety of the allotransplantation of these $\mathrm{CD}_{3} 4^{+}$cells and to evaluate the resistance to the HIV-1 virus in HIV-infected patients after infusion of these CD34+ cells. Prior to the cell infusion, the patients will be treated with anti-retroviral therapy to achieve undetectable HIV-1 virus in the peripheral blood. During the follow-up, HIV-1 viral load, CD4 ${ }^{+} \mathrm{T}$ cells, and CCR5-negative cell counts in the peripheral blood will be monitored in HIV-infected patients.

Another promising ex vivo gene therapy clinical trial is the combined use of CRISPR/Cas9 gene-editing technology and chimeric antigen receptor (CAR)-based cancer immunotherapy (NCT03166878). The CAR-expressed T cells can be engineered to recognize leukemia antigens such as CD19 on B cells for the treatment of relapsed or refractory B-cell malignancies. However, the cost and technical difficulties in the production and expansion of CAR-expressed $\mathrm{T}$ cells have hindered the wide application of personalized autologous CAR-T cell therapy. Thus, universal CAR-T cells derived from healthy unrelated donors are developed to overcome some of these drawbacks. To evade hostmediated immunity and deliver anti-leukemic effects without graft-versus-host disease in patients with relapsed or refractory B-cell malignancies, gene-disrupted allogeneic CD19-directed BB $\zeta$ CAR-T cells (known as UCART019) are developed by combining the lentiviral delivery of CAR and CRISPR mRNA electroporation to disrupt both of the endogenous T-cell receptor (TCR) and beta-2 microglobulin (B2M) genes. The TCR and B2M play important roles in triggering the immune response; hence, disrupting both of these genes could minimize immunogenicity associated with allotransplantation. The primary goal of these allogeneic CD19 CAR-T cells is to evaluate the feasibility, safety, and in vivo persistence of UCART019 adoptively transferred 


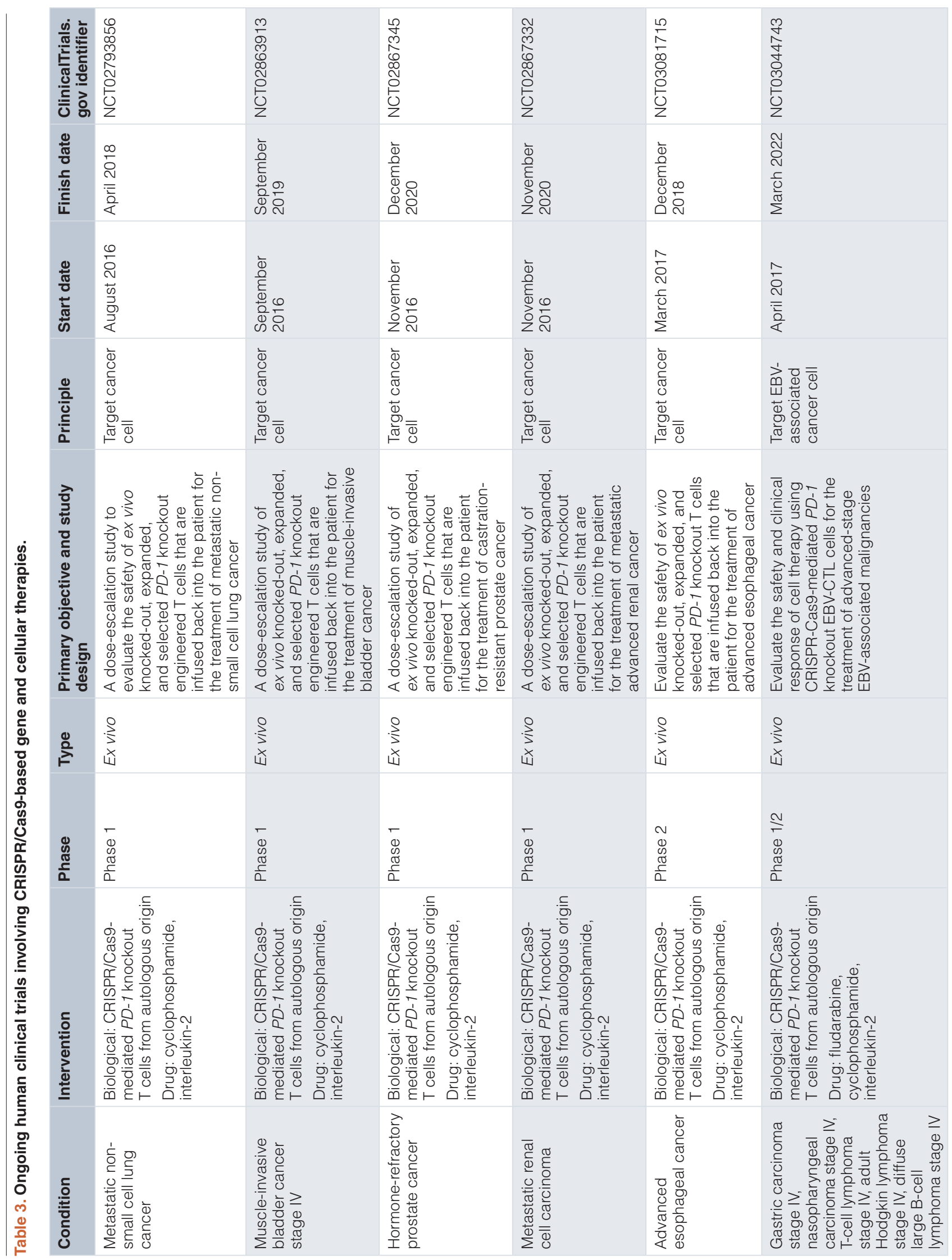




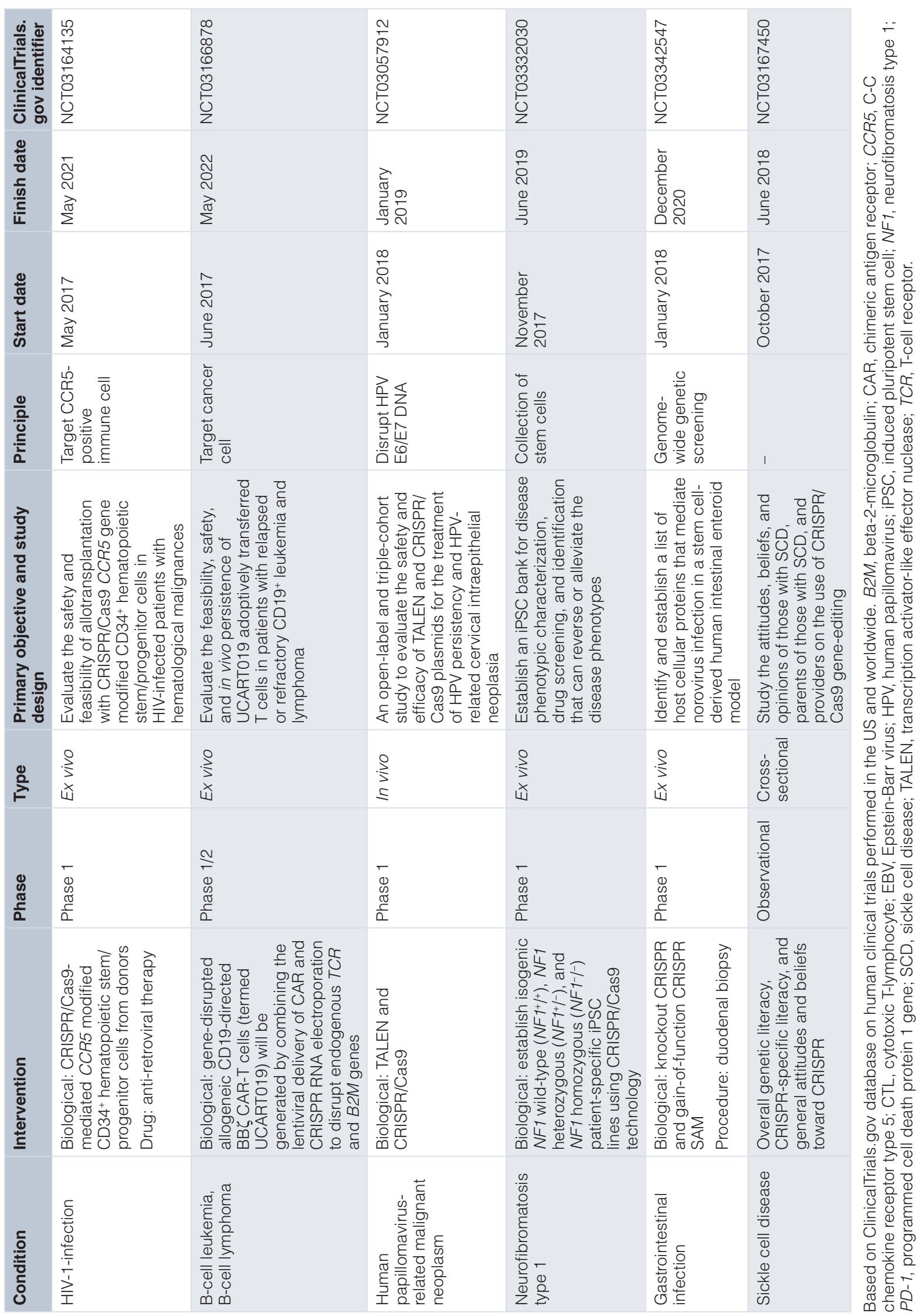


$\mathrm{T}$ cells in patients with relapsed or refractory $\mathrm{CD} 19^{+}$leukemia and lymphoma. The amount of UCART019 cells (engraftment), humoral host immunity, and anti-tumor response upon UCART019 cell infusions will be monitored.

Owing to the tissue complexities in humans, toxicity concern, and potential complications such as host immune response following a high dose of AAV vectors used to achieve significant therapeutic efficacy ${ }^{107}$, the AAV-CRISPR viral delivery system is restricted to ex vivo gene editing or genetic manipulation in animals. One of the promising strategies to overcome this issue was to mutagenize the surface-exposed tyrosine residues on the AAV capsid in order to avoid AAV degradation by the host cell proteasome machinery and to improve AAV intracellular trafficking to the nucleus, which can lead to high transduction efficiency at lower vector doses ${ }^{107}$. The combined use of capsidmodified and genome-modified next-generation AAV vectors has allowed higher transduction efficiency and transgene expression at further reduced doses ${ }^{108}$. To date, the AAV-CRISPR geneediting system was tested in non-human animals only, but the first in vivo gene therapy using CRISPR/Cas9 technology will be carried out in human clinical trials soon. In January 2018, an open-label and triple-cohort study will be conducted to evaluate the safety of therapeutic doses and the dosing regimen of CRISPR/ Cas9 plasmid to treat human papillomavirus (HPV) persistency and HPV-related cervical intraepithelial neoplasia. Given the important roles that E6 and E7 play in HPV-driven carcinogenesis, CRISPR/Cas9-mediated disruption of HPV16 and HPV18 E6/E7 DNA could be an attractive approach for therapeutic interventions by significantly downregulating the expression of E6/E7 in order to induce HPV-associated cell apoptosis and to inhibit cell growth.

\section{Promises and hurdles associated with the AAV-CRISPR system for future clinical applications}

An increasing number of studies in mice have clearly demonstrated that the combined use of tissue-specific minimal promoters, natural and engineered AAV serotypes, different routes of administration, and small Cas9 orthologues enables efficient packaging and precise delivery of AAV-CRISPR vectors for targeted in vivo genome editing in specific tissues with minimized side effects. Nevertheless, special considerations are required when selecting tissue-specific promoters, natural and engineered AAV serotypes, or routes of administration to avoid non-specific delivery and transgene expression of the AAV. In addition, the off-target effects, toxicity, and immunogenicity associated with CRISPR/Cas9 delivery remain to be fully resolved.

\section{Non-specific delivery and transgene expression}

Tissue-specific promoters and AAV serotypes might still be able to transduce and induce transgene expression in healthy tissues or other non-target organs if a strong promoter or a high dose of viral vectors is introduced into the body by intravenous injection. Despite a significant improvement in the efficiency and specificity of newly discovered natural and engineered AAV variants for systemic delivery in mice, the toxicity and side effects associated with the non-specific delivery of the transgenes to the non-target tissues and organs remain a concern ${ }^{13,89}$. It is easier to get delivery vehicles taken up by liver than other organs upon systemic injection. Therefore, it is more challenging to specifically target non-liver organs than liver via a systemic delivery approach. For instance, recently discovered synthetic vectors, AAV-PHP.B ${ }^{13}$ and tyrosine-mutant $\mathrm{AAV}^{89}$, were found to transduce the adult mouse central nervous system more efficiently and widely than the natural AAV9 after intravenous injection. However, these synthetic vectors can also transduce the liver and other peripheral organs upon systemic delivery ${ }^{13,89}$. In this case, local injections such as stereotaxic injection into the brain can minimize the possible complications or adverse side effects associated with non-specific expression of CRISPR in healthy tissues or other non-target organs.

\section{Off-target effects}

Even though CRISPR/Cas9 predominantly recognizes the intended target sites, a series of high-throughput genome-wide methods such as multiplex Digenome-seq ${ }^{109,110}$, ChIP-seq ${ }^{111,112}$, GUIDE-seq ${ }^{113}$, and whole-genome sequencing ${ }^{114}$ as well as targeted deep sequencing ${ }^{112}$, Cas9 toxicity screens ${ }^{115}$, and SITE-seq biochemical methods ${ }^{116}$ have revealed evidence of off-target effects due to target mismatch tolerance of CRISPR/Cas9. As inter-individual natural genetic variation can affect CRISPR/Cas9 specificity $^{117}$, a recently developed CIRCLE-seq approach could be used to identify genome-wide off-target mutations of CRISPR/Cas9 that are associated with cell type-specific single-nucleotide polymorphisms to provide personalized specificity profiles ${ }^{118}$. Notably, given the same target sequence of gRNA, off-target sites of Cas9 before and after being fused to a catalytic enzyme (for example, cytidine deaminase base editor and chromatin modifiers) could be different; therefore, independent assessment of their genome-wide specificities is recommended $^{119}$. Imprecise repair of Cas9-induced DNA double-stranded breaks can give rise to deleterious structural chromosomal rearrangements such as deletions, inversions, and translocations, which in turn may activate oncogenes or cause genome instability ${ }^{120}$. Hence, high-throughput screenings of CRISPR/Cas9 off-target activity and further improvement in the fidelity of CRISPR/Cas9 on-target activity are essential for safety in clinical gene transfer applications.

There are many ways to minimize CRISPR/Cas9 off-target effects in the human genome. For example, a recently developed RNA-targeting Cas9 (RCas9) system could avoid permanent off-target genetic lesions in DNA-mediated CRISPR-based therapeutics ${ }^{121}$. The RCas9 system consists of a fusion of rationally truncated dCas9 protein and PilT N-terminus (PIN) domain that can be packaged into the AAV vector for eliminating toxic microsatellite repeat expansion RNA or reducing repetitive RNA level without targeting the DNA ${ }^{121}$. With a similar strategy, systemic delivery of dCas9/gRNA by AAV9 significantly reduced pathological RNA foci, rescued chloride channel 1 protein expression, and decreased myotonia in myotonic dystrophy mice by impeding the transcription of expanded microsatellite repeats $^{122}$. Another way is to deliver purified Cas9 RNPs rather than plasmid expression vectors ${ }^{10,123}$. Despite some technical constraints in non-viral delivery methods for in vivo administration, the use of Cas9 RNPs can limit the duration of Cas9 
expression and decrease the chance of Cas9 nuclease cleaving at non-specific sites in a genome because of the rapid clearance from the cell ${ }^{10,123}$. Complementing the CRISPR-based editing capability with conditional genetic manipulation tools such as photoactivatable $\mathrm{Cas} 9^{124,125}$, chemical-inducible Cas $9^{126,127}$, or multiple inputs logic gate genetic circuits ${ }^{128,129}$ enables the precise spatial and temporal control of Cas9 activity inside the cell, which in turn leads to the reduction in off-target activity. Alternatively, a pair of Cas9 nickases ${ }^{130-132}$, dCas9-FokI ${ }^{133}$, or high-fidelity Cas9 variants such as SpCas9-HF1 $1^{134}$, eSpCas9 $9^{135}$, and HypaCas9 $9^{136}$ can be used to minimize undesired off-target mutagenesis.

The use of a scarless genome-editing strategy for targeted point mutation knock-in can also minimize unwanted mutation formations to favor the desired clean base editing outcomes ${ }^{137,138}$. For a point mutation knock-in, the efficiency of precise sequence replacement by CRISPR-mediated homology-directed repair (HDR) could be significantly increased by using asymmetric donor DNA ${ }^{139}$, HDR enhancer ${ }^{140}$, or short ssDNA donor oligonucleotides as a donor template instead of long plasmid donor ${ }^{139}$ or by inhibiting non-homologous end joining (NHEJ) activity ${ }^{141}$. Also, the artificial chimeric RNAs ${ }^{142}$ - truncated $^{73,113}$ and chemically modified $^{143}$ gRNAs-were shown to have lower off-target activity than the original gRNAs. A number of bioinformatics analysis tools such as GuideScan ${ }^{144}$, CRISPRdirect ${ }^{145}$, and Cas-OFFinder ${ }^{146}$ permit the specific design of gRNAs to avoid binding at the non-intended target sites in the human genome. The specificity of the gRNA designed can be improved by selecting a target sequence with two Gs at the $5^{\prime}$ terminus $^{131}$ and avoiding potential mismatches at the seed sequence or basepairing adjacent to the $\mathrm{PAM}^{147}$. Another innovative way to improve the specificity and reduce the toxicity of the CRISPR/ Cas9 is co-delivery of DNA decoys or competitive inhibitor oligonucleotides bearing all possible off-target sequences that can sequester and prevent the CRISPR/Cas9 from binding to the off-target sites within a host genome. A similar concept has been successfully demonstrated to alleviate the off-target effects of RNA interference by using RNA decoys to reduce the sense strand activity of shRNAs ${ }^{148}$, while artificial microRNA (miRNA) sponges have been used to inhibit miRNA function and its ability to regulate natural $\mathrm{mRNAs} \mathrm{s}^{149}$. In addition, a recently developed miRNA-responsive CRISPR/Cas9 switch could be useful for cell type-specific genome editing by sensing endogenous miRNA activities ${ }^{150}$.

\section{Immunogenicity}

Owing to the exogenous nature of AAV and CRISPR components, host immune responses can attenuate therapeutic effects and cause side effects. Thus, the toxicity and immunogenicity associated with AAV and CRISPR components should be circumvented for safer and higher efficacy in clinical gene therapy applications. Even though the AAV generally elicits a very mild immune response and does not induce extensive cellular damage in vivo, certain AAV serotypes such as AAV9 may evoke humoral immune responses, as indicated by the presence of capsid-specific antibodies ${ }^{50}$. While transient immunosuppression is one of the possible ways to mitigate the host immune response following the delivery of AAV vectors ${ }^{151}$, it is not feasible for long-term therapeutic treatments of chronic diseases and is prone to adverse complications such as infections and malignancies. Empty capsid mutants can be used as decoys to overcome pre-existing humoral immunity by adsorbing antibodies in the bloodstream upon systemic delivery of both empty and functional $\mathrm{AAVs}^{152}$. Alternatively, the AAV capsids can be genetically engineered or mutated to reduce the binding affinity and the neutralizing effects of AAV antibodies ${ }^{15,153-155}$. In addition to AAVs, the presence of Cas9-specific antibodies in Cas9-exposed animals indicated that Cas9 could evoke deleterious cellular and humoral immune responses in vivo ${ }^{50}$. Expression of Cas9 in vivo could affect the transcription of the genes associated with the immunological processes. This in turn may destabilize the host immune system, elicit significant cellular infiltration or expansion, and induce enlargement of the draining lymph nodes with increased immune cell counts ${ }^{50}$. The Cas9-responsive T-cell clonotype described previously could serve as a distinctive biomarker to assess Cas9-specific immunity before clinical implementation of the CRISPR system ${ }^{50}$. To minimize the immune response due to prolonged expression of Cas9, conditional genome editing with the self-limiting CRISPR/Cas9 system $^{58}$ or light-inducible $e^{124,125}$ or chemical-inducible ${ }^{126,127}$ Cas9 can be used to minimize the duration of Cas 9 expression in the body.

\section{Conclusions and perspectives}

The AAV-CRISPR system holds enormous translational potential to develop curative therapeutic options for patients with severe and life-threatening genetic diseases by permanently editing disease-causing or risk genes in the human body. The delivery, efficacy, and safety issues in treating complex heritable and somatic disorders have to be fully resolved to fulfill this promise. Thus far, the ex vivo approach has been adopted to overcome the technical challenges associated with the in vivo delivery of the AAV-CRISPR viral vectors in humans. The ex vivo gene-editing approach is commonly used for the therapeutic treatment of blood disorders, cancers, and immune-related diseases. In the near future, in vivo genome editing is expected to offer better avenues to treat a wide range of human hereditary diseases in adults. In vivo gene therapy in humans provides several advantages over the ex vivo approach, and sometimes a combination of the two is necessary to achieve a good therapeutic outcome. For example, in vivo photoreceptor cell rescue can be used to halt retinal degeneration to preserve existing vision, while ex vivo photoreceptor cell replacement can be used to restore lost vision in patients with retinal dystrophy ${ }^{156}$. After in vivo photoreceptor cell rescue, the retinal environment may become more permissive for transplanted photo-receptor survival and de novo synaptogenesis via the ex vivo approach ${ }^{156}$.

The AAV vector already has a long history of success in clinical trials in vivo, but owing to the relatively recent arrival of CRISPR technology, the AAV-CRISPR system has yet to be tested in vivo for human gene therapy trials. Nevertheless, three ongoing human clinical trials (NCT03041324, NCT02702115, and NCT02695160) have used AAV vectors to deliver zinc finger nucleases, an earlier and well-established gene-editing tool, to the liver tissue for the treatment of hemophilia B and mucopolysaccharidosis. Similarly, the AAV vectors may be 
used for CRISPR delivery for human clinical trials in the future. Excitingly, the first in vivo human gene therapy trials using CRISPR/Cas9 plasmid administration to treat human HPVrelated malignant neoplasms will be initiated in January 2018 (NCT03057912).

Although it is more feasible to deliver the transgene ex vivo than in vivo, the in vivo approach eliminates the need for cell transplants. Therefore, in vivo therapy can avoid potential graft-versus-host disease and immunosuppression-related complications such as infections and malignancies, as seen in cellular therapy. Recently, various genetically engineered AAV variants or structure-guided derivations of AAV mutants have been developed to significantly improve the efficiency and specificity for in vivo delivery ${ }^{157}$. Compared with existing AAV serotypes, these newly engineered AAV capsids enabled higher transduction efficiency at a targeted tissue by altering the native tropism of the AAV capsid $^{13-15,158}$ and had low immunogenicity by evading preexisting anti-AAV capsid neutralizing antibodies in the human body ${ }^{159,160}$. Given the encouraging results obtained with the next-generation synthetic AAV capsids in animals, this synthetic AAV vector may also be used to deliver CRISPR/Cas9 transgene in humans for in vivo genome editing in the near future. Further improvement in the performance of engineered AAV variants and CRISPR components is necessary to realize the full potential of the AAV-CRISPR system for in vivo genome editing.

\section{Competing interests}

No competing interests were disclosed.

\section{Grant information}

This work was funded by National Institutes of Health grants AG017242, GM104459, and CA180126 (to Yousin Suh).

The funders had no role in study design, data collection and analysis, decision to publish, or preparation of the manuscript.
1. Lau CH, Suh Y: Genome and Epigenome Editing in Mechanistic Studies of Human Aging and Aging-Related Disease. Gerontology. 2017; 63(2): 103-17. PubMed Abstract | Publisher Full Text | Free Full Text

2. Barrangou R, Doudna JA: Applications of CRISPR technologies in research and beyond. Nat Biotechnol. 2016; 34(9): 933-41. PubMed Abstract | Publisher Full Text

3. F Cong L, Ran FA, Cox D, et al.: Multiplex genome engineering using CRISPR/Cas systems. Science. 2013; 339(6121): 819-23. PubMed Abstract | Publisher Full Text | Free Full Text | F1000 Recommendation

4. Ran FA, Cong L, Yan WX, et al.: In vivo genome editing using Staphylococcus aureus Cas9. Nature. 2015; 520(7546): 186-91. PubMed Abstract | Publisher Full Text | Free Full Text

5. Kim E, Koo T, Park SW, et al:: In vivo genome editing with a small Cas9 orthologue derived from Campylobacter jejuni. Nat Commun. 2017; 8: 14500. PubMed Abstract | Publisher Full Text | Free Full Text

6. F Komor AC, Badran AH, Liu DR: CRISPR-Based Technologies for the Manipulation of Eukaryotic Genomes. Cell. 2017; 168(1-2): 20-36. PubMed Abstract | Publisher Full Text | Free Full Text | F1000 Recommendation

7. Xiong X, Chen M, Lim WA, et al.: CRISPR/Cas9 for Human Genome Engineering and Disease Research. Annu Rev Genomics Hum Genet. 2016; 17: 131-54. PubMed Abstract | Publisher Full Text

8. Kouranova E, Forbes K, Zhao G, et al:: CRISPRs for Optimal Targeting: Delivery of CRISPR Components as DNA, RNA, and Protein into Cultured Cells and Single-Cell Embryos. Hum Gene Ther. 2016; 27(6): 464-75. PubMed Abstract | Publisher Full Text | Free Full Text

9. Liang X, Potter J, Kumar S, et al:: Rapid and highly efficient mammalian cell engineering via Cas9 protein transfection. J Biotechnol. 2015; 208: 44-53. PubMed Abstract | Publisher Full Text

10. Kim S, Kim D, Cho SW, et al:: Highly efficient RNA-guided genome editing in human cells via delivery of purified Cas 9 ribonucleoproteins. Genome Res. 2014; 24(6): 1012-9.

PubMed Abstract | Publisher Full Text | Free Full Text

11. Fornito A, Zalesky A, Breakspear M: The connectomics of brain disorders. Nat Rev Neurosci. 2015; 16(3): 159-72. PubMed Abstract | Publisher Full Text

12. Staahl BT, Benekareddy M, Coulon-Bainier C, et al.: Efficient genome editing in the mouse brain by local delivery of engineered Cas9 ribonucleoprotein complexes. Nat Biotechnol. 2017; 35(5): 431-4. PubMed Abstract | Publisher Full Text

13. F Deverman BE, Pravdo PL, Simpson BP, et al:: Cre-dependent selection yields AAV variants for widespread gene transfer to the adult brain. Nat Biotechnol. 2016; 34(2): 204-9.

PubMed Abstract | Publisher Full Text | Free Full Text | F1000 Recommendation

14. Choudhury SR, Harris AF, Cabral DJ, et al:: Widespread Central Nervous System
Gene Transfer and Silencing After Systemic Delivery of Novel AAV-AS Vector. Mol Ther. 2016; 24(4): 726-35.

PubMed Abstract | Publisher Full Text | Free Full Text

15. Choudhury SR, Fitzpatrick Z, Harris AF, et al.: In vivo Selection Yields AAV-B1 Capsid for Central Nervous System and Muscle Gene Therapy. Mol Ther. 2016; 24(7): 1247-57.

PubMed Abstract | Publisher Full Text | Free Full Text

16. Yin H, Kauffman KJ, Anderson DG: Delivery technologies for genome editing. Nat Rev Drug Discov. 2017; 16(6): 387-99. PubMed Abstract | Publisher Full Text

17. Song M: The CRISPR/Cas9 system: Their delivery, in vivo and ex vivo applications and clinical development by startups. Biotechnol Prog. 2017; 33(4): 1035-45.

PubMed Abstract | Publisher Full Text

18. He ZY, Men K, Qin Z, et al:: Non-viral and viral delivery systems for CRISPRCas9 technology in the biomedical field. Sci China Life Sci. 2017; 60(5): 458-67. PubMed Abstract | Publisher Full Text

19. Williams MR, Fricano-Kugler CJ, Getz SA et al: A Retroviral CRISPR-Cas9 System for Cellular Autism-Associated Phenotype Discovery in Developing Neurons. Sci Rep. 2016; 6: 25611. PubMed Abstract | Publisher Full Text | Free Full Text

20. F Koike-Yusa H, Li Y, Tan EP, et al.: Genome-wide recessive genetic screening in mammalian cells with a lentiviral CRISPR-guide RNA library. Nat Biotechnol. 2014; 32(3): 267-73.

PubMed Abstract | Publisher Full Text | F1000 Recommendation

21. Kabadi AM, Ousterout DG, Hilton IB, et al.: Multiplex CRISPR/Cas9-based genome engineering from a single lentiviral vector. Nucleic Acids Res. 2014; 42(19): e147.

PubMed Abstract | Publisher Full Text | Free Full Text

22. Wang D, Mou H, Li S, et al:: Adenovirus-Mediated Somatic Genome Editing of Pten by CRISPR/Cas9 in Mouse Liver in Spite of Cas9-Specific Immune Responses. Hum Gene Ther. 2015; 26(7): 432-42. PubMed Abstract | Publisher Full Text | Free Full Text

23. Cheng $\mathrm{R}$, Peng J, Yan $\mathrm{Y}$, et al.: Efficient gene editing in adult mouse livers via adenoviral delivery of CRISPR/Cas9. FEBS Lett. 2014; 588(21): 3954-8. PubMed Abstract | Publisher Full Text

24. Schmidt F, Grimm D: CRISPR genome engineering and viral gene delivery: a case of mutual attraction. Biotechnol J. 2015; 10(2): 258-72. PubMed Abstract | Publisher Full Text

25. Swiech $\mathrm{L}$, Heidenreich $\mathrm{M}$, Banerjee $\mathrm{A}$, et al.: In vivo interrogation of gene function in the mammalian brain using CRISPR-Cas9. Nat Biotechnol. 2015; 33(1): 102-6. PubMed Abstract | Publisher Full Text | Free Full Text

26. Mansouri M, Ehsaei Z, Taylor V, et al.: Baculovirus-based genome editing in primary cells. Plasmid. 2017; 90: 5-9. PubMed Abstract | Publisher Full Text 
27. Mansouri M, Bellon-Echeverria I, Rizk A, et al:: Highly efficient baculovirusmediated multigene delivery in primary cells. Nat Commun. 2016; 7: 11529. PubMed Abstract | Publisher Full Text | Free Full Text

28. Chen X, Gonçalves MA: Engineered Viruses as Genome Editing Devices. Mol Ther. 2016; 24(3): 447-57.

PubMed Abstract | Publisher Full Text | Free Full Text

29. Kwang TW, Zeng X, Wang S: Manufacturing of AcMNPV baculovirus vectors to enable gene therapy trials. Mol Ther Methods Clin Dev. 2016; 3: 15050 PubMed Abstract | Publisher Full Text | Free Full Text

30. Epstein BE, Schaffer DV: Combining Engineered Nucleases with Adenoassociated Viral Vectors for Therapeutic Gene Editing. Adv Exp Med Biol. 2017 1016: 29-42.

PubMed Abstract | Publisher Full Text | Free Full Text

31. Mingozzi F, High KA: Therapeutic in vivo gene transfer for genetic disease using AAV: progress and challenges. Nat Rev Genet. 2011; 12(5): 341-55. PubMed Abstract | Publisher Full Text

32. Senís E, Fatouros C, Große S, et al.: CRISPR/Cas9-mediated genome engineering: an adeno-associated viral (AAV) vector toolbox. Biotechnol J. 2014; 9(11): 1402-12. PubMed Abstract | Publisher Full Text

33. Zhu H, Lau C, Goh S, et al:: Baculoviral transduction facilitates TALEN-mediated targeted transgene integration and Cre/LoxP cassette exchange in humaninduced pluripotent stem cells. Nucleic Acids Res. 2013; 41(19): e180. PubMed Abstract | Publisher Full Text | Free Full Text

34. Joung J, Konermann S, Gootenberg JS, et al.: Genome-scale CRISPR-Cas9 knockout and transcriptional activation screening. Nat Protoc. 2017; 12(4): 828-63.

PubMed Abstract | Publisher Full Text | Free Full Text

35. F Klann TS, Black JB, Chellappan M, et al.: CRISPR-Cas9 epigenome editing enables high-throughput screening for functional regulatory elements in the human genome. Nat Biotechnol. 2017; 35(6): 561-8.

PubMed Abstract | Publisher Full Text | Free Full Text | F1000 Recommendation

36. Morris SJ, Turner AV, Green N, et al:: Laboratory-Scale Production of Replication-Deficient Adenovirus Vectored Vaccines. Methods Mol Biol. 2016; 1349: 121-35.

PubMed Abstract | Publisher Full Text

37. Garnier A, Côté J, Nadeau I, et al.: Scale-up of the adenovirus expression system for the production of recombinant protein in human $293 \mathrm{~S}$ cells. Cytotechnology. 1994; 15(1-3): 145-55.

PubMed Abstract | Publisher Full Tex

38. Fricano-Kugler CJ, Williams MR, Salinaro JR, et al.: Designing, Packaging, and Delivery of High Titer CRISPR Retro and Lentiviruses via Stereotaxic Injection. $J$ Vis Exp. 2016; (111)

PubMed Abstract | Publisher Full Text | Free Full Text

$39 \mathrm{Yi}$ Y, Noh MJ, Lee KH: Current advances in retroviral gene therapy. Curr Gene Ther. 2011; 11(3): 218-28.

PubMed Abstract | Publisher Full Text | Free Full Text

40. Dropulić B: Lentiviral vectors: their molecular design, safety, and use in laboratory and preclinical research. Hum Gene Ther. 2011; 22(6): 649-57. PubMed Abstract | Publisher Full Text

41. Mátrai J, Chuah MK, VandenDriessche T: Recent advances in lentiviral vector development and applications. Mol Ther. 2010; 18(3): 477-90.

PubMed Abstract | Publisher Full Text | Free Full Text

42. Li C, Guan X, Du T, et al:: Inhibition of HIV-1 infection of primary CD4+ T-cells by gene editing of CCR5 using adenovirus-delivered CRISPR/Cas9. J Gen Virol. 2015; 96(8): 2381-93.

PubMed Abstract | Publisher Full Tex

43. Gwiazda KS, Grier AE, Sahni J, et al.: High Efficiency CRISPR/Cas9-mediated Gene Editing in Primary Human T-cells Using Mutant Adenoviral E4orf6/ E1b55k "Helper" Proteins. Mol Ther. 2016; 24(9): 1570-80.

PubMed Abstract | Publisher Full Text | Free Full Text

44. St George JA: Gene therapy progress and prospects: adenoviral vectors. Gene Ther. 2003; 10(14): 1135-41.

PubMed Abstract | Publisher Full Tex

45. Kochanek S: High-capacity adenoviral vectors for gene transfer and somatic gene therapy. Hum Gene Ther. 1999; 10(15): 2451-9.

PubMed Abstract | Publisher Full Text

46. Lusky M: Good manufacturing practice production of adenoviral vectors for clinical trials. Hum Gene Ther. 2005; 16(3): 281-91. PubMed Abstract | Publisher Full Text

47. Volpers $\mathrm{C}$, Kochanek S: Adenoviral vectors for gene transfer and therapy. J Gene Med. 2004; 6(Suppl 1): S164-71.

PubMed Abstract | Publisher Full Text

48. McConnell MJ, Imperiale MJ: Biology of adenovirus and its use as a vector for gene therapy. Hum Gene Ther. 2004; 15(11): 1022-33. PubMed Abstract | Publisher Full Text

49. $F$ Yang $Y$, Wang $L$, Bell $P$, et al:: A dual AAV system enables the Cas9mediated correction of a metabolic liver disease in newborn mice. $N$ at Biotechnol. 2016; 34(3): 334-8.

PubMed Abstract | Publisher Full Text | Free Full Text | F1000 Recommendation

50. Chew WL, Tabebordbar M, Cheng JK, et al:: A multifunctional AAV-CRISPR-Cas9 and its host response. Nat Methods. 2016; 13(10): 868-74

PubMed Abstract | Publisher Full Text | Free Full Tex

51. During MJ: Adeno-associated virus as a gene delivery system. Adv Drug Deliv Rev. 1997; 27(1): 83-94.

PubMed Abstract | Publisher Full Text

52. Kotterman MA, Schaffer DV: Engineering adeno-associated viruses for clinical gene therapy. Nat Rev Genet. 2014; 15(7): 445-51.

PubMed Abstract | Publisher Full Text | Free Full Text

53. Airenne $\mathrm{KJ}, \mathrm{Hu}$ YC, Kost TA, et al.: Baculovirus: an insect-derived vector for diverse gene transfer applications. Mol Ther. 2013; 21(4): 739-49. PubMed Abstract | Publisher Full Text | Free Full Text

54. Tabebordbar M, Zhu K, Cheng JKW, et al.: In vivo gene editing in dystrophic mouse muscle and muscle stem cells. Science. 2016; 351(6271): 407-11. PubMed Abstract | Publisher Full Text | Free Full Text

55. F Nelson $\mathrm{CE}$, Hakim $\mathrm{CH}$, Ousterout $\mathrm{DG}$, et al:: In vivo genome editing improves muscle function in a mouse model of Duchenne muscular dystrophy. Science. 2016; 351(6271): 403-7.

PubMed Abstract | Publisher Full Text | Free Full Text | F1000 Recommendation

56. F Long C, Amoasii L, Mireault AA, et al.: Postnatal genome editing partially restores dystrophin expression in a mouse model of muscular dystrophy. Science. 2016; 351(6271): 400-3.

PubMed Abstract | Publisher Full Text | Free Full Text | F1000 Recommendation

57. F Bengtsson NE, Hall JK, Odom GL, et al:: Muscle-specific CRISPR/Cas9 dystrophin gene editing ameliorates pathophysiology in a mouse model for Duchenne muscular dystrophy. Nat Commun. 2017; 8: 14454.

PubMed Abstract | Publisher Full Text | Free Full Text | F1000 Recommendation

58. F Ruan GX, Barry E, Yu D, et al.: CRISPR/Cas9-Mediated Genome Editing as a Therapeutic Approach for Leber Congenital Amaurosis 10. Mol Ther. 2017; 25(2): 331-41.

PubMed Abstract | Publisher Full Text | Free Full Text | F1000 Recommendation

59. F Hung SS, Chrysostomou V, Li F, et al:: AAV-Mediated CRISPR/Cas Gene Editing of Retinal Cells In vivo. Invest Ophthalmol Vis Sci. 2016; 57(7): 3470-6. PubMed Abstract | Publisher Full Text | F1000 Recommendation

60. F Yu W, Mookherjee S, Chaitankar V, et al:: Nrl knockdown by AAV-delivered CRISPR/Cas9 prevents retinal degeneration in mice. Nat Commun. 2017; 8: 14716.

PubMed Abstract | Publisher Full Text | Free Full Text | F1000 Recommendation

61. Yin $\mathrm{H}$, Song $\mathrm{CQ}$, Dorkin JR, et al.: Therapeutic genome editing by combined viral and non-viral delivery of CRISPR system components in vivo. Nat Biotechnol. 2016; 34(3): 328-33.

PubMed Abstract | Publisher Full Text | Free Full Text

62. Xie C, Zhang YP, Song L, et al:: Genome editing with CRISPR/Cas9 in postnatal mice corrects PRKAG2 cardiac syndrome. Cell Res. 2016; 26(10): 1099-111. PubMed Abstract | Publisher Full Text | Free Full Text

63. F Carroll KJ, Makarewich CA, McAnally J, et al.: A mouse model for adult cardiac-specific gene deletion with CRISPR/Cas9. Proc Natl Acad Sci U S A. 2016; 113(2): 338-43

PubMed Abstract | Publisher Full Text | Free Full Text | F1000 Recommendation

64. F Johansen AK, Molenaar B, Versteeg D, et al:: Postnatal Cardiac Gene Editing Using CRISPR/Cas9 With AAV9-Mediated Delivery of Short Guide RNAs Results in Mosaic Gene Disruption. Circ Res. 2017; 121(10): 1168-81. PubMed Abstract | Publisher Full Text | F1000 Recommendation

65. F Platt RJ, Chen S, Zhou Y, et al:: CRISPR-Cas9 knockin mice for genome editing and cancer modeling. Cell. 2014; 159(2): 440-55. PubMed Abstract | Publisher Full Text | Free Full Text | F1000 Recommendation

66. F Kleinstiver BP, Prew MS, Tsai SQ, et al.: Engineered CRISPR-Cas9 nucleases with altered PAM specificities. Nature. 2015; 523(7561): 481-5. PubMed Abstract | Publisher Full Text | Free Full Text | F1000 Recommendation

67. F Nishimasu H, Ran FA, Hsu PD, et al:: Crystal structure of Cas9 in complex with guide RNA and target DNA. Cell. 2014; 156(5): 935-49. PubMed Abstract | Publisher Full Text | Free Full Text | F1000 Recommendation

68. F Tervo DG, Hwang B, Viswanathan S, et al:: A Designer AAV Variant Permits Efficient Retrograde Access to Projection Neurons. Neuron. 2016; 92(2): 372-82. PubMed Abstract | Publisher Full Text | F1000 Recommendation

69. F Kemaladewi DU, Maino E, Hyatt $\mathrm{E}$, et al:: Correction of a splicing defect in a mouse model of congenital muscular dystrophy type 1A using a homologydirected-repair-independent mechanism. Nat Med. 2017; 23(8): 984-9. PubMed Abstract | Publisher Full Text | F1000 Recommendation

70. El Refaey M, Xu L, Gao Y, et al:: In vivo Genome Editing Restores Dystrophin Expression and Cardiac Function in Dystrophic Mice. Circ Res. 2017; 121(8): 923-9.

PubMed Abstract | Publisher Full Text | Free Full Text

71. Ohmori T, Nagao Y, Mizukami H, et al:: CRISPR/Cas9-mediated genome editing via postnatal administration of AAV vector cures haemophilia B mice. Sci Rep. 2017; 7(1): 4159 PubMed Abstract | Publisher Full Text | Free Full Text

72. F Yin C, Zhang T, Qu X, et al:: In vivo Excision of HIV-1 Provirus by saCas9 and Multiplex Single-Guide RNAs in Animal Models. Mol Ther. 2017; 25(5): 
1168-86.

PubMed Abstract | Publisher Full Text | Free Full Text | F1000 Recommendation

73. F Fu Y, Sander JD, Reyon D, et al.: Improving CRISPR-Cas nuclease specificity using truncated guide RNAs. Nat Biotechnol. 2014; 32(3): 279-84. PubMed Abstract | Publisher Full Text | Free Full Text | F1000 Recommendation

74. Davis KM, Pattanayak V, Thompson DB, et al:: Small molecule-triggered Cas9 protein with improved genome-editing specificity. Nat Chem Biol. 2015; 11(5): 316-8.

PubMed Abstract | Publisher Full Text | Free Full Text

75. F Yu C, Liu Y, Ma T, et al.: Small molecules enhance CRISPR genome editing in pluripotent stem cells. Cell Stem Cell. 2015; 16(2): 142-7.

PubMed Abstract | Publisher Full Text | Free Full Text | F1000 Recommendation

76. Monteys AM, Ebanks SA, Keiser MS, et al:: CRISPR/Cas9 Editing of the Mutant Huntingtin Allele In Vitro and In Vivo. Mol Ther. 2017; 25(1): 12-23.

PubMed Abstract | Publisher Full Text | Free Full Text

77. Jarrett KE, Lee CM, Yeh YH, et al:: Somatic genome editing with CRISPR/Cas9 generates and corrects a metabolic disease. Sci Rep. 2017; 7: 44624. PubMed Abstract | Publisher Full Text | Free Full Text

78. Guo Y, VanDusen NJ, Zhang L, et al:: Analysis of Cardiac Myocyte Maturation Using CASAAV, a Platform for Rapid Dissection of Cardiac Myocyte Gene Function In Vivo. Circ Res. 2017; 120(12): 1874-88. PubMed Abstract | Publisher Full Text | Free Full Text

79. F Chow RD, Guzman CD, Wang G, et al:: AAV-mediated direct in vivo CRISPR screen identifies functional suppressors in glioblastoma. Nat Neurosci. 2017; 20(10): 1329-41.

PubMed Abstract | Publisher Full Text | Free Full Text | F1000 Recommendation

80. F Murlidharan G, Sakamoto K, Rao L, et al.: CNS-restricted Transduction and CRISPR/Cas9-mediated Gene Deletion with an Engineered AAV Vector. Mol Ther Nucleic Acids. 2016; 5(7): e338.

PubMed Abstract | Publisher Full Text | Free Full Text | F1000 Recommendation

81. F de Solis CA, Ho A, Holehonnur R, et al:: The Development of a Viral Mediated CRISPR/Cas9 System with Doxycycline Dependent gRNA Expression for Inducible In vitro and In vivo Genome Editing. Front Mol Neurosci. 2016; 9: 70 PubMed Abstract | Publisher Full Text | Free Full Text | F1000 Recommendation

82. Nishiyama J, Mikuni T, Yasuda R: Virus-Mediated Genome Editing via Homology-Directed Repair in Mitotic and Postmitotic Cells in Mammalian Brain. Neuron. 2017; 96(4): 755-768.e5.

PubMed Abstract | Publisher Full Text | Free Full Text

83. Li Y, Kim J: Distinct roles of neuronal and microglial CB2 cannabinoid receptors in the mouse hippocampus. Neuroscience. 2017; 363: 11-25. PubMed Abstract | Publisher Full Text

84. Lin $\mathrm{H}, \mathrm{Hu} \mathrm{H}$, Duan W, et al: Intramuscular Delivery of scAAV9-hIGF1 Prolongs Survival in the hSOD1G93A ALS Mouse Model via Upregulation of D-Amino Acid Oxidase. Mol Neurobiol. 2016; 1-14. PubMed Abstract | Publisher Full Text

85. Huang $X$, Zhou G, Wu W, et al:: Genome editing abrogates angiogenesis in vivo. Nat Commun. 2017: 8(1): 112 .

PubMed Abstract | Publisher Full Text | Free Full Text

86. F Kaminski R, Bella $R$, Yin C, et al:: Excision of HIV-1 DNA by gene editing: a proof-of-concept in vivo study. Gene Ther. 2016; 23(8-9): 690-5. PubMed Abstract | Publisher Full Text | Free Full Text | F1000 Recommendation

87. F Grimm D, Lee JS, Wang L, et al.: In vitro and in vivo gene therapy vector evolution via multispecies interbreeding and retargeting of adeno-associated viruses. J Virol. 2008; 82(12): 5887-911.

PubMed Abstract | Publisher Full Text | Free Full Text | F1000 Recommendation

88. Hashimoto $\mathrm{H}$, Mizushima $\mathrm{T}$, Chijiwa $\mathrm{T}$, et al: Efficient production of recombinant adeno-associated viral vector, serotype DJ/8, carrying the GFP gene. Virus Res. 2017; 238: 63-8.

PubMed Abstract | Publisher Full Text

89. Iida A, Takino N, Miyauchi $\mathrm{H}$, et al:: Systemic delivery of tyrosine-mutant AAV vectors results in robust transduction of neurons in adult mice. Biomed Res Int. 2013; 2013: 974819 .

PubMed Abstract | Publisher Full Text | Free Full Text

90. McCarty DM, Monahan PE, Samulski RJ: Self-complementary recombinant adeno-associated virus (scAAV) vectors promote efficient transduction independently of DNA synthesis. Gene Ther. 2001; 8(16): 1248-54. PubMed Abstract | Publisher Full Text

91. Wang $X, X u Z$, Tian Z, et al:: The EF-1 $\alpha$ promoter maintains high-level transgene expression from episomal vectors in transfected CHO-K1 cells. J Cell Mol Med. 2017; 21(11): 3044-54.

PubMed Abstract | Publisher Full Text | Free Full Text

92. Teschendorf C, Warrington $\mathrm{KH} \mathrm{Jr}$, Siemann DW, et al:: Comparison of the EF-1 alpha and the CMV promoter for engineering stable tumor cell lines using recombinant adeno-associated virus. Anticancer Res. 2002; 22(6A): 3325-30. PubMed Abstract

93. Chung S, Andersson T, Sonntag KC, et al:: Analysis of different promoter systems for efficient transgene expression in mouse embryonic stem cell lines. Stem Cells. 2002; 20(2): 139-45. PubMed Abstract | Publisher Full Text | Free Full Text

94. Roelz R, Pilz IH, Mutschler M, et al.: Of mice and men: human RNA polymerase III promoter U6 is more efficient than its murine homologue for shRNA expression from a lentiviral vector in both human and murine progenitor cells.
Exp Hematol. 2010; 38(9): 792-7.

PubMed Abstract | Publisher Full Text

95. Mäkinen PI, Koponen JK, Kärkkäinen AM, et al: Stable RNA interference: comparison of $\mathrm{U} 6$ and $\mathrm{H} 1$ promoters in endothelial cells and in mouse brain $J$ Gene Med. 2006; 8(4): 433-41.

PubMed Abstract | Publisher Full Text

96. Sun $\mathrm{CP}, \mathrm{Wu} \mathrm{TH}$, Chen $\mathrm{CC}$, et al:: Studies of efficacy and liver toxicity related to adeno-associated virus-mediated RNA interference. Hum Gene Ther 2013; 24(8): 739-50.

PubMed Abstract | Publisher Full Text | Free Full Text

97. Larson MH, Gilbert LA, Wang X, et al.: CRISPR interference (CRISPRi) for sequence-specific control of gene expression. Nat Protoc. 2013; 8(11): 2180-96. PubMed Abstract | Publisher Full Text | Free Full Text

98. Ranganathan V, Wahlin K, Maruotti J, et al:: Expansion of the CRISPR-Cas9 genome targeting space through the use of $\mathrm{H} 1$ promoter-expressed guide RNAs. Nat Commun. 2014; 5: 4516. PubMed Abstract | Publisher Full Text | Free Full Text

99. Vidigal JA, Ventura A: Rapid and efficient one-step generation of paired gRNA CRISPR-Cas9 libraries. Nat Commun. 2015; 6: 8083. PubMed Abstract | Publisher Full Text | Free Full Text

100. Saraiva J, Nobre RJ, Pereira de Almeida L: Gene therapy for the CNS using AAVs: The impact of systemic delivery by AAV9. J Control Release. 2016; 241 94-109.

PubMed Abstract | Publisher Full Text

101. Vagner T, Dvorzhak A, Wójtowicz AM, et al:: Systemic application of AAV vectors targeting GFAP-expressing astrocytes in Z-Q175-KI Huntington's disease mice. Mol Cell Neurosci. 2016; 77: 76-86. PubMed Abstract | Publisher Full Text

102. Tanguy $Y$, Biferi MG, Besse A, et al:: Systemic AAVrh10 provides higher transgene expression than AAV9 in the brain and the spinal cord of neonatal mice. Front Mol Neurosci. 2015; 8: 36

PubMed Abstract | Publisher Full Text | Free Full Text

103. Cyranoski D: CRISPR gene-editing tested in a person for the first time. Nature. 2016; 539(7630): 479

PubMed Abstract | Publisher Full Text

104. Cyranoski D: Chinese scientists to pioneer first human CRISPR trial. Nature. 2016; 535(7613): 476-7. PubMed Abstract | Publisher Full Text

105. Costa R, Carneiro BA, Agulnik M, et al.: Toxicity profile of approved anti-PD-1 monoclonal antibodies in solid tumors: a systematic review and meta-analysis of randomized clinical trials. Oncotarget. 2017; 8(5): 8910-20.

PubMed Abstract | Publisher Full Text | Free Full Text

106. Zhang T, Xie J, Arai S, et al:: The efficacy and safety of anti-PD-1/PD-L1 antibodies for treatment of advanced or refractory cancers: a meta-analysis. Oncotarget. 2016; 7(45): 73068-79.

PubMed Abstract | Publisher Full Text | Free Full Text

107. Zhong L, Li B, Mah CS, et al.: Next generation of adeno-associated virus 2 vectors: point mutations in tyrosines lead to high-efficiency transduction at lower doses. Proc Natl Acad Sci U S A. 2008; 105(22): 7827-32. PubMed Abstract | Publisher Full Text | Free Full Text

108. Ling C, Li B, Ma W, et al.: Development of Optimized AAV Serotype Vectors for High-Efficiency Transduction at Further Reduced Doses. Hum Gene Ther Methods. 2016; 27(4): 143-9.

PubMed Abstract | Publisher Full Text | Free Full Text

109. Kim D, Kim S, Kim S, et al.: Genome-wide target specificities of CRISPR-Cas9 nucleases revealed by multiplex Digenome-seq. Genome Res. 2016; 26(3): 406-15.

PubMed Abstract | Publisher Full Text | Free Full Text

110. Kim D, Bae S, Park J, et al.: Digenome-seq: genome-wide profiling of CRISPRCas9 off-target effects in human cells. Nat Methods. 2015; 12(3): 237-43, 1 p following 243

PubMed Abstract | Publisher Full Text

111. Kuscu C, Arslan S, Singh R, et al:: Genome-wide analysis reveals characteristics of off-target sites bound by the Cas9 endonuclease. Nat Biotechnol. 2014; 32(7): 677-83.

PubMed Abstract | Publisher Full Text

112. F O'Geen H, Henry IM, Bhakta MS, et al:: A genome-wide analysis of Cas9 binding specificity using ChIP-seq and targeted sequence capture. Nucleic Acids Res. 2015; 43(6): 3389-404

PubMed Abstract | Publisher Full Text | Free Full Text | F1000 Recommendation

113. F Tsai SQ, Zheng Z, Nguyen NT, et al.: GUIDE-seq enables genome-wide profiling of off-target cleavage by CRISPR-Cas nucleases. Nat Biotechnol. 2015 33(2): 187-97.

PubMed Abstract | Publisher Full Text | Free Full Text | F1000 Recommendation

114. Yang L, Grishin D, Wang G, et al:: Targeted and genome-wide sequencing revea single nucleotide variations impacting specificity of Cas 9 in human stem cells. Nat Commun. 2014; 5: 5507.

PubMed Abstract | Publisher Full Text | Free Full Text

115. Morgens DW, Wainberg M, Boyle EA, et al:: Genome-scale measurement of offtarget activity using Cas9 toxicity in high-throughput screens. Nat Commun. 2017; 8: 15178.

PubMed Abstract | Publisher Full Text | Free Full Text

116. Cameron P, Fuller CK, Donohoue PD, et al.: Mapping the genomic landscape of 
CRISPR-Cas9 cleavage. Nat Methods. 2017; 14(6): 600-6. PubMed Abstract | Publisher Full Text

117. Scott DA, Zhang F: Implications of human genetic variation in CRISPR-based therapeutic genome editing. Nat Med. 2017; 23(9): 1095-101. PubMed Abstract | Publisher Full Text

118. F Tsai SQ, Nguyen NT, Malagon-Lopez J, et al.: CIRCLE-seq: a highly sensitive in vitro screen for genome-wide CRISPR-Cas9 nuclease off-targets. Nat Methods. 2017; 14(6): 607-14

PubMed Abstract | Publisher Full Text | F1000 Recommendation

119. Kim D, Lim K, Kim ST, et al.: Genome-wide target specificities of CRISPR RNAguided programmable deaminases. Nat Biotechnol. 2017; 35(5): 475-80. PubMed Abstract | Publisher Full Text

120. Koo T, Lee J, Kim JS: Measuring and Reducing Off-Target Activities of Programmable Nucleases Including CRISPR-Cas9. Mol Cells. 2015; 38(6): 475-81.

PubMed Abstract | Publisher Full Text | Free Full Text

121. F Batra R, Nelles DA, Pirie E, et al:: Elimination of Toxic Microsatellite Repeat Expansion RNA by RNA-Targeting Cas9. Cell. 2017; 170(5): 899-912.e10. PubMed Abstract | Publisher Full Text | F1000 Recommendation

122. F Pinto BS, Saxena T, Oliveira R, et al.: Impeding Transcription of Expanded Microsatellite Repeats by Deactivated Cas9. Mol Cell. 2017; 68(3): 479-490.e5. PubMed Abstract | Publisher Full Text | F1000 Recommendation

123. Kim K, Park SW, Kim JH, et al:: Genome surgery using Cas9 ribonucleoproteins for the treatment of age-related macular degeneration. Genome Res. 2017; 27(3): 419-26.

PubMed Abstract | Publisher Full Text | Free Full Text

124. Nihongaki $Y$, Kawano F, Nakajima T, et al.: Photoactivatable CRISPR-Cas9 for optogenetic genome editing. Nat Biotechnol. 2015; 33(7): 755-60. PubMed Abstract | Publisher Full Text

125. F Polstein LR, Gersbach CA: A light-inducible CRISPR-Cas9 system for control of endogenous gene activation. Nat Chem Biol. 2015; 11(3): 198-200. PubMed Abstract | Publisher Full Text | Free Full Text | F1000 Recommendation

126. Dow LE, Fisher J, O'Rourke KP, et al.: Inducible in vivo genome editing with CRISPR-Cas9. Nat Biotechnol. 2015; 33(4): 390-4. PubMed Abstract | Publisher Full Text | Free Full Text

127. Liu KI, Ramli MN, Woo CW, et al:: A chemical-inducible CRISPR-Cas9 system for rapid control of genome editing. Nat Chem Biol. 2016; 12(11): 980-7. PubMed Abstract | Publisher Full Text

128. Liu $Y$, Zeng $Y$, Liu $L$, et al.: Synthesizing AND gate genetic circuits based on CRISPR-Cas9 for identification of bladder cancer cells. Nat Commun. 2014; $\mathbf{5}$ : 5393

PubMed Abstract | Publisher Full Text

129. Weinberg BH, Pham NT, Caraballo LD, et al.: Large-scale design of robust genetic circuits with multiple inputs and outputs for mammalian cells. Nat Biotechnol. 2017; 35(5): 453-62. PubMed Abstract | Publisher Full Text | Free Full Text

130. Shen B, Zhang W, Zhang J, et al.: Efficient genome modification by CRISPRCas9 nickase with minimal off-target effects. Nat Methods. 2014; 11(4): 399-402. PubMed Abstract | Publisher Full Text

131. Cho SW, Kim S, Kim Y, et al:: Analysis of off-target effects of CRISPR/Casderived RNA-guided endonucleases and nickases. Genome Res. 2014; 24(1): 132-41.

PubMed Abstract | Publisher Full Text | Free Full Text

132. F Ran FA, Hsu PD, Lin CY, et al:: Double nicking by RNA-guided CRISPR Cas9 for enhanced genome editing specificity. Cell. 2013; 154(6): 1380-9. PubMed Abstract | Publisher Full Text | Free Full Text | F1000 Recommendation

133. Guilinger JP, Thompson DB, Liu DR: Fusion of catalytically inactive Cas9 to Fokl nuclease improves the specificity of genome modification. Nat Biotechnol. 2014; 32(6): 577-82.

PubMed Abstract | Publisher Full Text | Free Full Text

134. F Kleinstiver BP, Pattanayak V, Prew MS, et al:: High-fidelity CRISPR-Cas9 nucleases with no detectable genome-wide off-target effects. Nature. 2016; 529(7587): 490-5.

PubMed Abstract | Publisher Full Text | Free Full Text | F1000 Recommendation

135. F Slaymaker IM, Gao L, Zetsche B, et al:: Rationally engineered Cas nucleases with improved specificity. Science. 2016; 351(6268): 84-8. PubMed Abstract | Publisher Full Text | Free Full Text | F1000 Recommendation

136. Chen JS, Dagdas YS, Kleinstiver BP, et al:: Enhanced proofreading governs CRISPR-Cas9 targeting accuracy. Nature. 2017; 550(7676): 407-10. PubMed Abstract | Publisher Full Text

137. F Komor AC, Kim YB, Packer MS, et al:: Programmable editing of a target base in genomic DNA without double-stranded DNA cleavage. Nature. 2016; 533(7603): 420-4.

PubMed Abstract | Publisher Full Text | Free Full Text | F1000 Recommendation

138. F Kim K, Ryu SM, Kim ST, et al.: Highly efficient RNA-guided base editing in mouse embryos. Nat Biotechnol. 2017; 35(5): 435-7. PubMed Abstract | Publisher Full Text | F1000 Recommendation
139. Richardson CD, Ray GJ, DeWitt MA, et al:: Enhancing homology-directed genome editing by catalytically active and inactive CRISPR-Cas 9 using asymmetric donor DNA. Nat Biotechnol. 2016; 34(3): 339-44.

PubMed Abstract | Publisher Full Text

140. Song J, Yang D, Xu J, et al.: RS-1 enhances CRISPR/Cas9- and TALEN-mediated knock-in efficiency. Nat Commun. 2016; 7: 10548. PubMed Abstract | Publisher Full Text | Free Full Text

141. F Maruyama T, Dougan SK, Truttmann MC, et al:: Increasing the efficiency of precise genome editing with CRISPR-Cas9 by inhibition of nonhomologous end joining. Nat Biotechnol. 2015; 33(5): 538-42. PubMed Abstract | Publisher Full Text | Free Full Text | F1000 Recommendation

142. Cho SW, Kim S, Kim JM, et al:: Targeted genome engineering in human cells with the Cas9 RNA-guided endonuclease. Nat Biotechnol. 2013; 31(3): 230-2. PubMed Abstract | Publisher Full Text

143. Hendel A, Bak RO, Clark JT, et al:: Chemically modified guide RNAs enhance CRISPR-Cas genome editing in human primary cells. Nat Biotechnol. 2015; 33(9): 985-9.

PubMed Abstract | Publisher Full Text | Free Full Text

144. Perez AR, Pritykin Y, Vidigal JA, et al:: GuideScan software for improved single and paired CRISPR guide RNA design. Nat Biotechnol. 2017; 35(4): 347-9. PubMed Abstract | Publisher Full Text | Free Full Text

145. Naito $\mathrm{Y}$, Hino $\mathrm{K}$, Bono $\mathrm{H}$, et al:: CRISPRdirect: software for designing CRISPR/ Cas guide RNA with reduced off-target sites. Bioinformatics. 2015; 31(7): 1120-3. PubMed Abstract | Publisher Full Text | Free Full Text

146. Bae S, Park J, Kim JS: Cas-OFFinder: a fast and versatile algorithm that searches for potential off-target sites of Cas9 RNA-guided endonucleases. Bioinformatics. 2014; 30(10): 1473-5. PubMed Abstract | Publisher Full Text | Free Full Text

147. Zhang XH, Tee LY, Wang XG, et al.: Off-target Effects in CRISPR/Cas9-mediated Genome Engineering. Mol Ther Nucleic Acids. 2015; 4(11): e264. PubMed Abstract | Publisher Full Text | Free Full Text

148. F Mockenhaupt S, Grosse S, Rupp D, et al.: Alleviation of off-target effects rom vector-encoded shRNAs via codelivered RNA decoys. Proc Natl Acad Sci U S A. 2015; 112(30): E4007-16.

PubMed Abstract | Publisher Full Text | Free Full Text | F1000 Recommendation

149. Tay FC, Lim JK, Zhu H, et al.: Using artificial microRNA sponges to achieve microRNA loss-of-function in cancer cells. Adv Drug Deliv Rev. 2015; 81: 117-27. PubMed Abstract | Publisher Full Text

150. F Hirosawa M, Fujita Y, Parr CJC, et al:: Cell-type-specific genome editing with a microRNA-responsive CRISPR-Cas9 switch. Nucleic Acids Res. 2017; 45(13): e118.

PubMed Abstract | Publisher Full Text | Free Full Text | F1000 Recommendation

151. Manning WC, Zhou S, Bland MP, et al:: Transient immunosuppression allows transgene expression following readministration of adeno-associated viral vectors. Hum Gene Ther. 1998; 9(4): 477-85.

PubMed Abstract | Publisher Full Text

152. Mingozzi $F$, Anguela XM, Pavani G, et al.: Overcoming preexisting humoral immunity to AAV using capsid decoys. Sci Transl Med. 2013; 5(194): $194 \mathrm{ra92.}$ PubMed Abstract | Publisher Full Text | Free Full Text

153. Huttner NA, Girod A, Perabo L, et al.: Genetic modifications of the adenoassociated virus type 2 capsid reduce the affinity and the neutralizing effects of human serum antibodies. Gene Ther. 2003; 10(26): 2139-47. PubMed Abstract | Publisher Full Text

154. Arbetman AE, Lochrie M, Zhou $S$, et al:: Novel caprine adeno-associated virus (AAV) capsid (AAV-Go.1) is closely related to the primate AAV-5 and has unique tropism and neutralization properties. J Virol. 2005; 79(24): 15238-45. PubMed Abstract | Publisher Full Text | Free Full Text

155. Maheshri N, Koerber JT, Kaspar BK, et al: Directed evolution of adenoassociated virus yields enhanced gene delivery vectors. Nat Biotechnol. 2006; 24(2): 198-204 PubMed Abstract | Publisher Full Tex

156. F Bakondi B: In vivo versus ex vivo CRISPR therapies for retinal dystrophy. Expert Rev Ophthalmol. 2016; 11(6): 397-400. PubMed Abstract | Publisher Full Text | Free Full Text | F1000 Recommendation

157. Grimm D, Büning H: Small But Increasingly Mighty: Latest Advances in AAV Vector Research, Design, and Evolution. Hum Gene Ther. 2017; 28(11): 1075-86. PubMed Abstract | Publisher Full Text

158. Paulk NK, Pekrun K, Zhu E, et al:: Bioengineered AAV Capsids with Combined High Human Liver Transduction In vivo and Unique Humoral Seroreactivity. Mol Ther. 2017; pii: S1525-0016(17)30437-9. PubMed Abstract | Publisher Full Text

159. Tse LV, Klinc KA, Madigan VJ, et al:: Structure-guided evolution of antigenically distinct adeno-associated virus variants for immune evasion. Proc Natl Acad Sci U S A. 2017: 114(24): E4812-E4821. PubMed Abstract | Publisher Full Text | Free Full Text

160. Li C, Wu S, Albright B, et al.: Development of Patient-specific AAV Vectors After Neutralizing Antibody Selection for Enhanced Muscle Gene Transfer. Mol Ther. 2016; 24(1): 53-65.

PubMed Abstract | Publisher Full Text | Free Full Text 


\section{Open Peer Review}

\section{Current Peer Review Status:}

\section{Editorial Note on the Review Process}

Faculty Reviews are review articles written by the prestigious Members of Faculty Opinions. The articles are commissioned and peer reviewed before publication to ensure that the final, published version is comprehensive and accessible. The reviewers who approved the final version are listed with their names and affiliations.

\section{The reviewers who approved this article are:}

\section{Version 1}

\section{Dirk Grimm}

Department of Infectious Diseases, Virology, Heidelberg University Hospital, Heidelberg, Germany Competing Interests: No competing interests were disclosed.

\section{Jin-Soo Kim}

Department of Chemistry, Seoul National University, Seoul, 151-742, South Korea

Competing Interests: No competing interests were disclosed.

The benefits of publishing with F1000Research:

- Your article is published within days, with no editorial bias

- You can publish traditional articles, null/negative results, case reports, data notes and more

- The peer review process is transparent and collaborative

- Your article is indexed in PubMed after passing peer review

- Dedicated customer support at every stage

For pre-submission enquiries, contact research@f1000.com 